\title{
Burundi: Ex Post Assessment of Longer-Term Program Engagement
}

This Ex Post Assessment of Longer-Term Program Engagement for Burundi was prepared by a staff team of the International Monetary Fund as background documentation for the periodic consultation with the member country. It is based on the information available at the time it was completed on June 29, 2011. The views expressed in this document are those of the staff team and do not necessarily reflect the views of the government of Burundi or the Executive Board of the IMF.

The policy of publication of staff reports and other documents by the IMF allows for the deletion of market-sensitive information.

Copies of this report are available to the public from

International Monetary Fund • Publication Services

$70019^{\text {th }}$ Street, N.W. • Washington, D.C. 20431

Telephone: (202) 623-7430 • Telefax: (202) 623-7201

E-mail: publications@imf.org Internet: http://www.imf.org

\section{International Monetary Fund Washington, D.C.}




\title{
INTERNATIONAL MONETARY FUND
}

\section{BURUNDI}

\section{Ex Post Assessment of Longer-Term Program Engagement}

\author{
Prepared by an Interdepartmental Staff Team ${ }^{1}$
}

Authorized for Distribution by the African and Strategy, Policy, and Review Departments

June 29, 2011

Contents

Abbreviations and Acronyms ...... 3

Key Issues 4

I. Introduction .5

II. Macroeconomic Developments and Performance under the PRGF/ECF Arrangements ....6

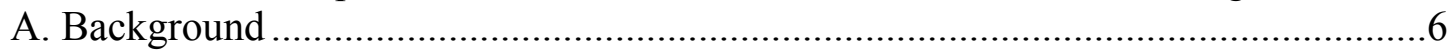

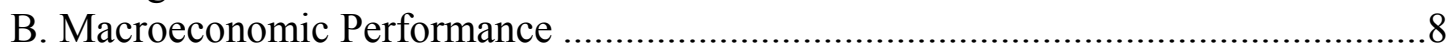

III. The IMF-supported Programs: Design, Assessment and Lessons...................................16

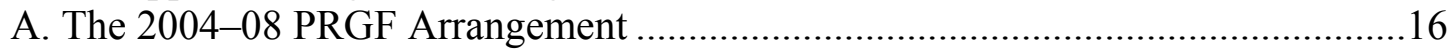

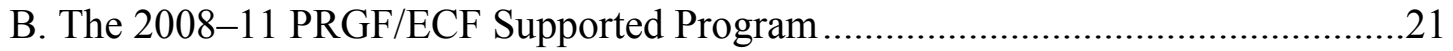

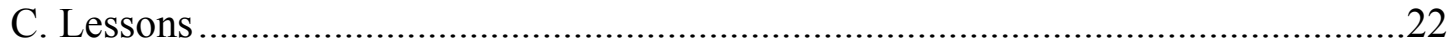

IV. Outline of a Strategy for Future Fund Engagement....................................................25

Table

1. Conditionality per review: Burundi Relative to other PRGF/ECF Supported Programs ....20

2. Selected Economic and Financial Indicators, 2004-11 .............................................. 30

Figures

1. Selected Development Indicators ..................................................................... 7

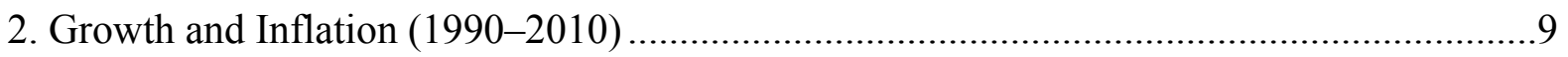

\footnotetext{
${ }^{1}$ The team comprised Xavier Debrun (head, FAD), Mika Saito (SPR), Iacovos Ioannou (AFR), and Bertrand Gruss (FAD). The report benefited from insights of present and past members of the Fund and World Bank teams working on Burundi.
} 


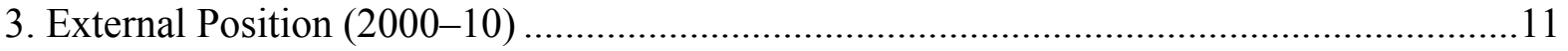

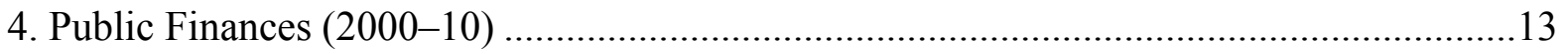

5. Selected Cross-Country Comparisons …....................................................................28

Boxes

1. HIPC Initiative, Poverty Reduction and Debt Sustainability........................................18

2. Coffee Sector Reform .............................................................................................. 19

3. East African Integration: A Game Changer? .............................................................29

Appendices

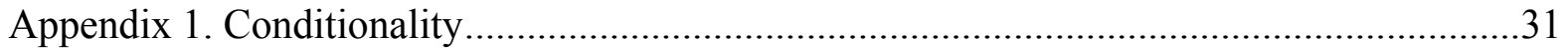

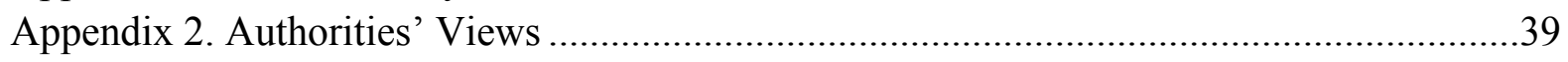




\section{Abbreviations AND ACRONYMS}

$\begin{array}{ll}\text { EAC } & \text { East African Community } \\ \text { ECF } & \text { Extended Credit Facility } \\ \text { FAD } & \text { Fiscal Affairs Department } \\ \text { FSAP } & \text { Financial Sector Assessment Program } \\ \text { HIPC } & \text { Highly Indebted Poor Country } \\ \text { MCM } & \text { Monetary and Capital Market Department } \\ \text { MDG } & \text { Millennium Development Goal } \\ \text { MDRI } & \text { Multilateral Debt Relief Initiative } \\ \text { OBR } & \text { Office Burundais des Recettes } \\ \text { PFM } & \text { Public Financial Management } \\ \text { PRGF } & \text { Poverty Reduction and Growth Facility } \\ \text { SME } & \text { Small and Medium-Sized Enterprises } \\ \text { TA } & \text { Technical Assistance }\end{array}$




\section{KEY ISSUES}

- $\quad$ Since the Arusha Accord in 2000-the first step toward peace after a decade of civil strife-Burundi's economy has begun to recover, but performance is constrained by weak institutions and governance, small and inefficient markets, poor infrastructure, and scarce capital, skills, and technology.

- Growth has rebounded to pre-conflict levels (still below regional peers) and is vulnerable to exogenous shocks. Constraints to growth are many and the need for structural reforms is correspondingly large, but progress is hampered by fractious post-conflict politics, very low capacities, and continued fragility.

- Catalyzed by Fund-supported programs, a massive surge in aid was absorbed and spent, stimulating domestic demand, but leaving the public sector vulnerable to fickle foreign assistance. Progress was made on reforms aimed at improving the conduct of monetary and fiscal policies, but was much slower in other areas, especially the coffee sector (the main source of income for half of the population).

- Burundi needs a growth strategy based on reforms that alleviate key bottlenecks and guarantee stability-oriented macroeconomic policies. Priorities for macroeconomic policies include greater exchange rate flexibility to better absorb terms-of-trade shocks, and the need to save part of the growth dividends to build fiscal buffers and restore debt sustainability.

- A new Fund program would help Burundi cope with these daunting challenges by preserving donor's confidence, boosting policy credibility and predictability, and building up capacities through technical assistance. 


\section{INTRODUCTION}

1. This report reviews the experience of the Fund's longer-term engagement in Burundi since 2004, and draws the lessons for future cooperation with the authorities. The paper assesses two Fund-supported programs: the January 2004 Poverty Reduction and Growth Facility (PRGF, expired in January 2008), and the July 2008 PRGF (later renamed Extended Credit Facility, or ECF expiring in August 2011). A successor ECF is expected to be requested before the end of 2011 .

2. Burundi's extreme poverty, post-conflict environment, and persistent fragility created considerable risks to program implementation, calling for extensive flexibility in engagement. Emerging from decades of civil strife and political instability, Burundi is one of the poorest countries in the world, with narrow markets, volatile income, scarce capital and skilled labor, weak institutions, fractious politics, and fragile peace. In these conditions, the design, monitoring and implementation of an effective Fund-supported program faces daunting challenges. Flexibility and adaptability proved essential to remain productively involved during this difficult transition toward a more durable peace (the last rebel group signed a formal peace deal only in mid-2008). The Fund's engagement arguably played an important role in the economic and social stabilization of the country by (i) providing an anchor for stability-oriented macroeconomic policies; (ii) catalyzing a rapid increase in external aid flows; and (iii) fostering steady - albeit slow — progress in unlocking some of the main constraints to growth through structural reforms and intensive technical assistance (TA).

3. There is a clear case for the Fund to remain engaged in Burundi for the foreseeable future. First, a very low income base combined with an only nascent growth takeoff suggests that Burundi is likely to remain strongly dependent on external support, in which the Fund's engagement plays a catalytic and stabilizing role. Second, the Fund's support would continue to lend additional credibility to the authorities' economic and financial program, a pre-condition for an attractive investment climate. Finally, in close cooperation with donors, the Fund's TA and policy advice would remain instrumental in strengthening institutions and capacities.

4. The remainder of this report is organized as follows. After an analysis of macroeconomic developments and performance during the period under review (Section II), the design and achievements of each Fund-supported program are assessed, focusing on three dimensions (Section III): the design of effective conditionality, the coordination with donors, and the role of TA. Lessons for future Fund engagement are discussed in Section IV. 


\section{Macroeconomic Developments and Performance Under the PRGF/ECF ARRANGEMENTS (2004-11)}

\section{A. Background}

5. Decades of ethnic tensions and inherent vulnerability to exogenous shocks have left Burundi among the least developed countries in the world, with real GDP per capita hovering well below its 1970 level. Civil war tore Burundi apart along ethnic lines for much of the 1990 s, leaving more than 300,000 casualties and about a million refugees. A power-sharing agreement between the two main ethnic groups (the Arusha accord) was signed in 2000. A political transition started in 2003 - after major combats ended - to culminate with the 2010 elections. Despite steady improvements in civil peace and political stability during the period under review, economic development remained constrained by weak institutions and governance, small and inefficient markets (Burundi is landlocked), poor infrastructure, and scarcity of capital, skills and technology (Figure 1). These weaknesses are inherently persistent. Combined with continued fragility, they have weighed on economic performance, explaining in part why Burundi has been lagging behind the growth acceleration observed in many sub-Saharan countries since the beginning of the century (Figure 1, and the October 2008 IMF Regional Economic Outlook-Africa). Dominated by agriculture - with coffee and tea as the main cash crops - the economy is vulnerable to large weather-related and terms-of-trade shocks.

6. In this challenging environment, various headwinds undermine macroeconomic performance. The first is the particular difficulty to enact ambitious structural reforms. As they eliminate or redistribute rents, reforms can create paralyzing conflicts among constituencies and groups. Ideally, a broad political consensus driven by a shared strategic vision is therefore needed to advance reforms. However, in an already fractious and unstable political environment, incentives to avoid major conflicts by delaying difficult measures are instead magnified. Secondly, limited technical and administrative capacities constrain the effective implementation of policies, putting adequate prioritization and sequencing at a premium and augmenting the risk of a backlash. Third, vulnerability to shocks complicates the conduct of macroeconomic policies and discourages investment, with adverse effects on growth and poverty reduction. Finally, the lack of policy space and dependency on fickle foreign aid flows can affect policy continuity and predictability, with adverse feedback effects on the business climate and potential growth. ${ }^{2}$

\footnotetext{
${ }^{2}$ Dabla-Norris and others (2010, IMF Working Paper No. 10/240) show that development aid tends to be procyclical - except in the case of large idiosyncratic shock affecting the recipient-and that it contracts sharply during economic downturns in donor countries. Also, governance concerns (e.g., related to corruption scandals, etc.) can lead to a disruptive stop-and-go pattern.
} 
Figure 1. Burundi: Selected Development Indicators

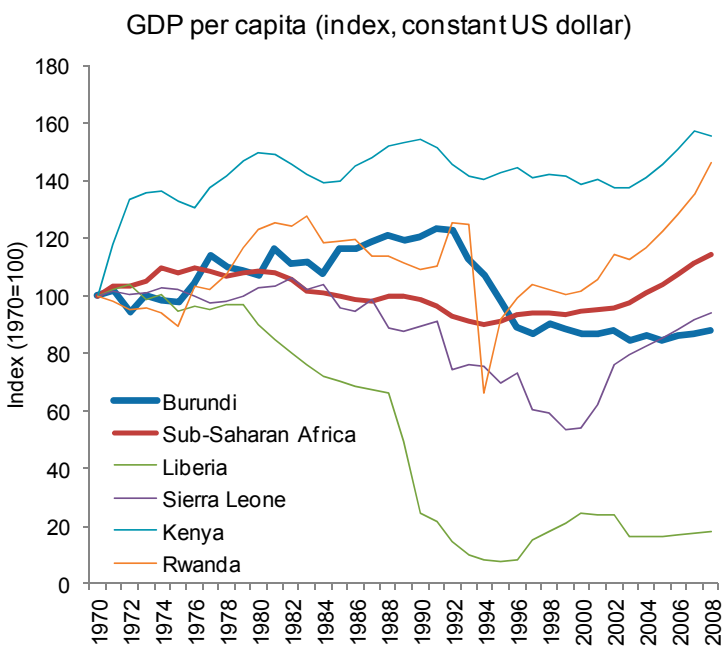
Perception of Corruption (Rank in the World)

Source: World Bank, World development Indicators (2010)

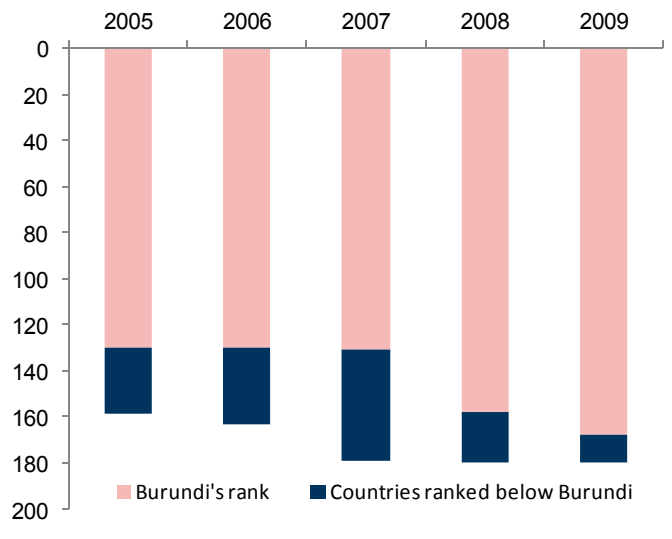

Source: Transparency International (2005-2009).
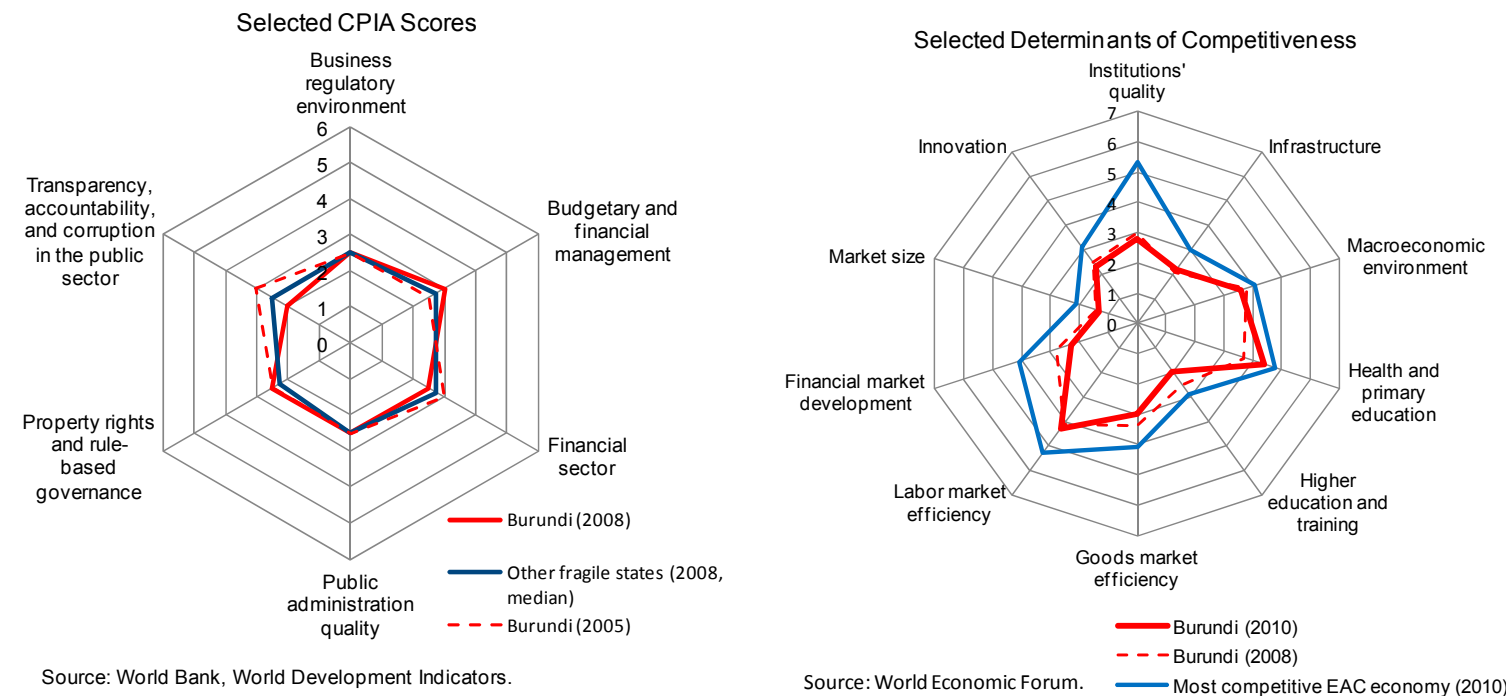

Source: World Bank, World Development Indicators.

Grants (in percent of GDP)

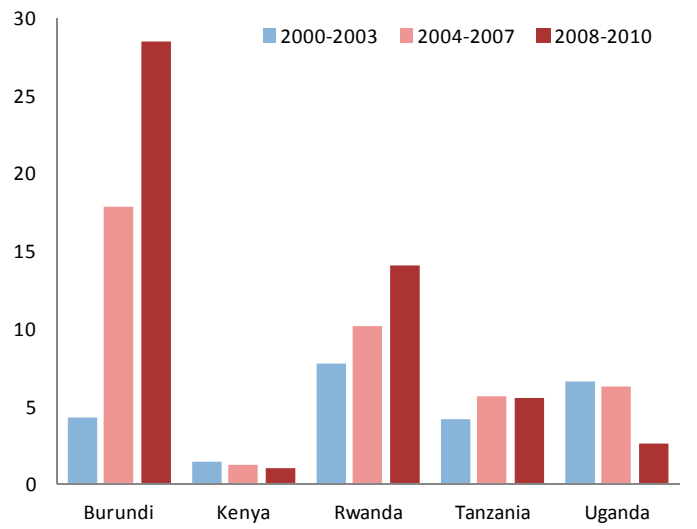

Grants: Disbursed minus Programmed (in percent of GDP)

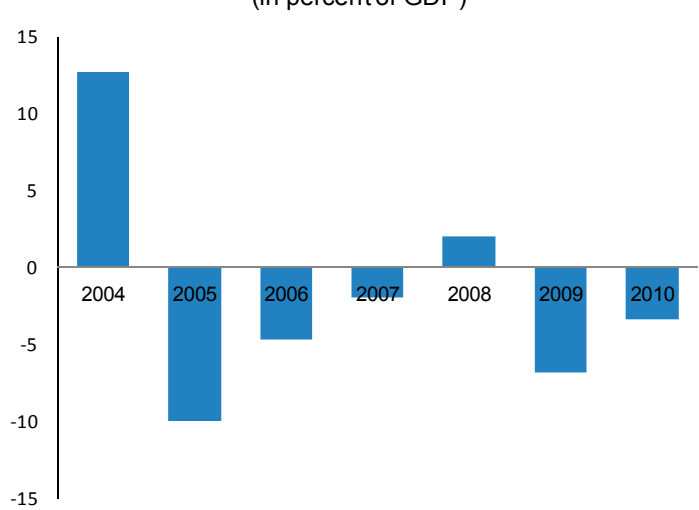

Source: IMF World Economic outlook.

Sources: Burundese authorities and IMF staff calculations 


\section{B. Macroeconomic Performance}

7. Burundi has made significant progress toward greater macroeconomic stability, but structural reforms have been slow, frustrating chances of growth acceleration. While performance under the first PRGF arrangement (2004-08) was affected by large external shocks (volatile coffee production and commodity prices) and damaging governance events, major steps were taken to improve the conduct of monetary and fiscal policies, to deal with the fiscal challenges of peace building, and to gain and retain donors' confidence. Improved prospects of a lasting peace and further significant progress in the area of public financial management (PFM) and revenue administration helped consolidate these gains under the second PRGF/ECF (2008-11). However, institutions remain weak and little progress has been made in liberalizing the economy, especially goods and credit markets, impeding investment and private sector growth. Also, the economy's vulnerability to price shocks complicates the conduct of monetary policy, and to the extent that their social impact needs to be addressed, of fiscal policy too.

\section{GDP per capita has bottomed out, with trend growth slowly returning toward} pre-conflict levels, while GDP volatility has decreased noticeably since 2005 (Figure 2). The key drivers of real GDP growth in Burundi have been agriculture - and especially coffee-donor-related activities, including investment projects, and government spending. Poor coffee harvests in 2005 and 2007 led to significant growth shortfalls, whereas strong agricultural output and donor-financed investment helped Burundi weather the impact of the food and energy price spike and the global economic and financial crisis ${ }^{3}$ in 2009. In this uncertain context, program forecasts often erred on the side of optimism in predicting the strength of recoveries and medium-term growth, reflecting in part unexpected shock persistence.

\section{Trend inflation declined over the period, but remains relatively high and} volatile, due mainly to fickle food and energy prices. Despite generally prudent monetary policies aided by important reforms of monetary policy instruments and improved liquidity management, controlling inflation has been challenging. With a consumption basket dominated by items with volatile prices such as foodstuff, a series of adverse price shocks prevented consumer price inflation from stabilizing around the programs' targets (4-5 percent under the first PRGF and less than 10 percent under the second program). In addition, episodes of budget stress largely related to lumpy aid disbursements have at times complicated liquidity and reserve management, as the government had to rely on central bank financing.

\footnotetext{
${ }^{3}$ Given its embryonic financial sector and a low openness to trade (trade flows represent about 30 percent of GDP), the global crisis affected Burundi mainly through a decline in remittances and lower coffee prices.
} 
Figure 2. Burundi: Growth and Inflation (1990-2010)
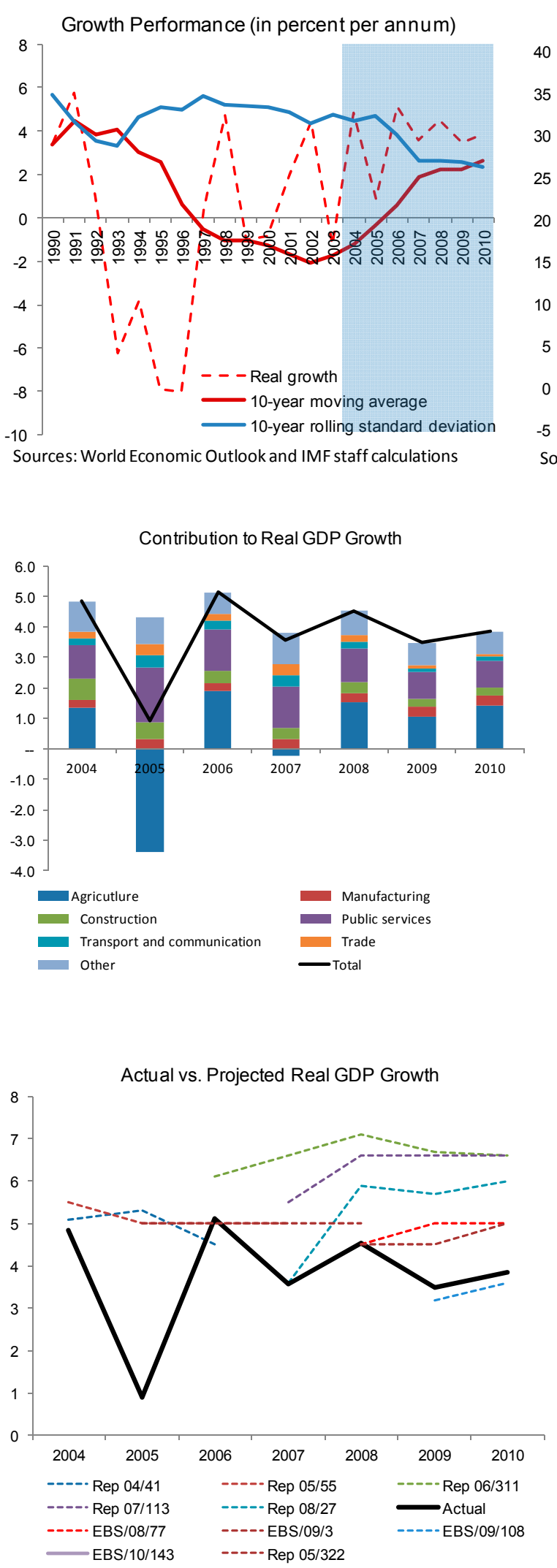

Inflation (in percent per annum, end-of-period)

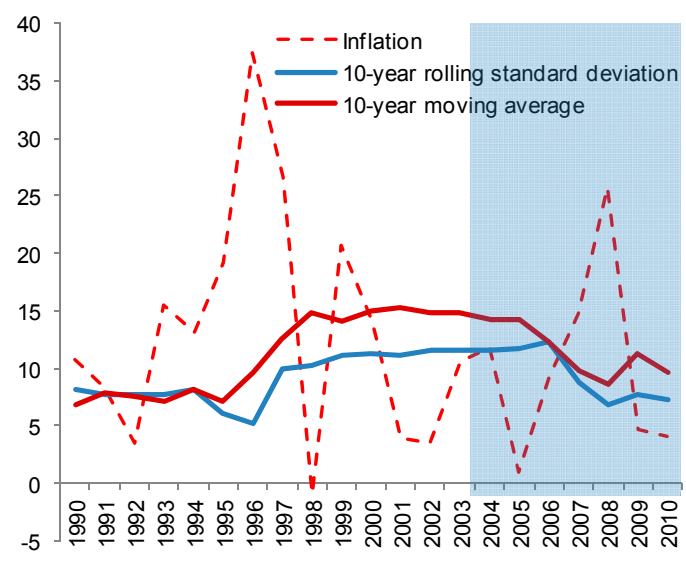

Sources: World Economic Outlook and IMF staff calculations.
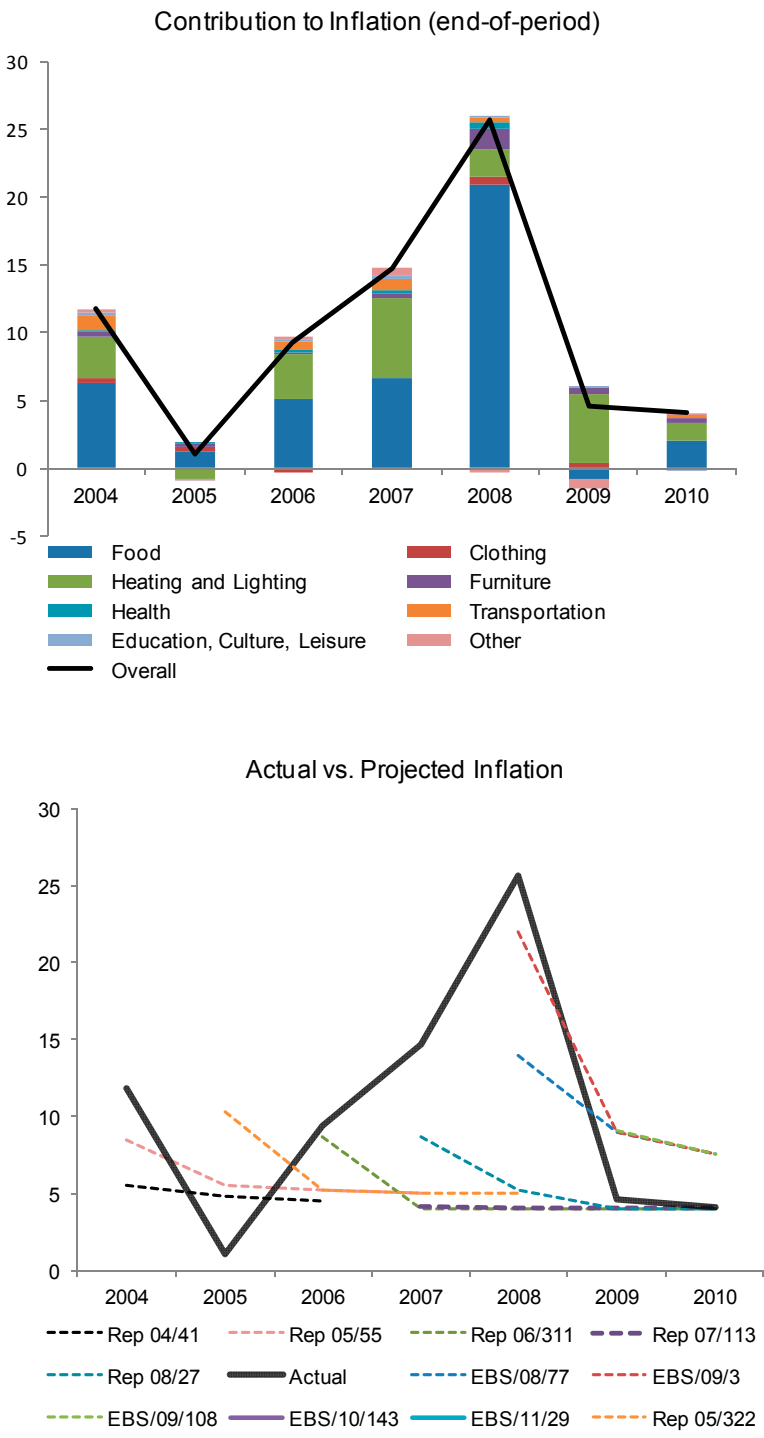


\section{The evolution of the external position and exchange rates is consistent with a good absorption of scaled-up aid.}

a. Over the first half of the period under review, the current account (including official transfers) deteriorated in line with the trade balance, reflecting broadly stagnant coffee exports and rising imports (Figure 3). A sharp increase in the volume of coffee exports and improving terms of trade narrowed the trade gap between 2008 and 2010, whereas the current account benefited further from the lower external debt service associated with the HIPC and MDRI initiatives. The deterioration of the external account was generally less pronounced than envisaged by staff under the first PRGF, and the post-2008 turnaround ended up weaker than expected under the program. Official reserves increased over the period - often more slowly than programmed - to reach 5 months of imports in 2010 (including the 2010 SDR allocation), a comfortable level but a quantitatively modest rise compared to the cumulative surge in aid.

b. The real effective exchange rate exhibited a mild appreciating trend. In nominal effective terms, however, the exchange rate has been moving sideways since mid-2008 due to a de facto shadowing of the US dollar. While such policy provided a clear nominal anchor and sheltered exporters (exports are invoiced in US dollars) and financial institutions from exchange rate risk, it constrained the responsiveness of monetary policy to terms-of-trade shocks.

c. The combination of larger current account deficits and some real appreciation is consistent with the absorption of aid inflows and the induced reallocation of resources toward non-tradable sectors, such as social services and construction. The only moderate increase in reserves suggests that the absorption has been largely complete, which is welcome given the magnitude of the needs, but underscores the vulnerability of the external position to possible reversals.

\section{Despite substantial debt relief, Burundi is still at high risk of external debt} distress, owing to a very low export base. Debt relief obtained under the HIPC and MDRI initiatives reduced Burundi's debt burden considerably (Figure 3). However, the latest debt sustainability analysis ${ }^{4}$ and indicators suggest that the risk of debt distress remains elevated, with the present value of total external debt still well above the threshold of 100 percent of exports of goods and services.

\footnotetext{
${ }^{4}$ See EBS/10/143, Sup. 2.
} 
Figure 3. Burundi: External Position (2000-10)
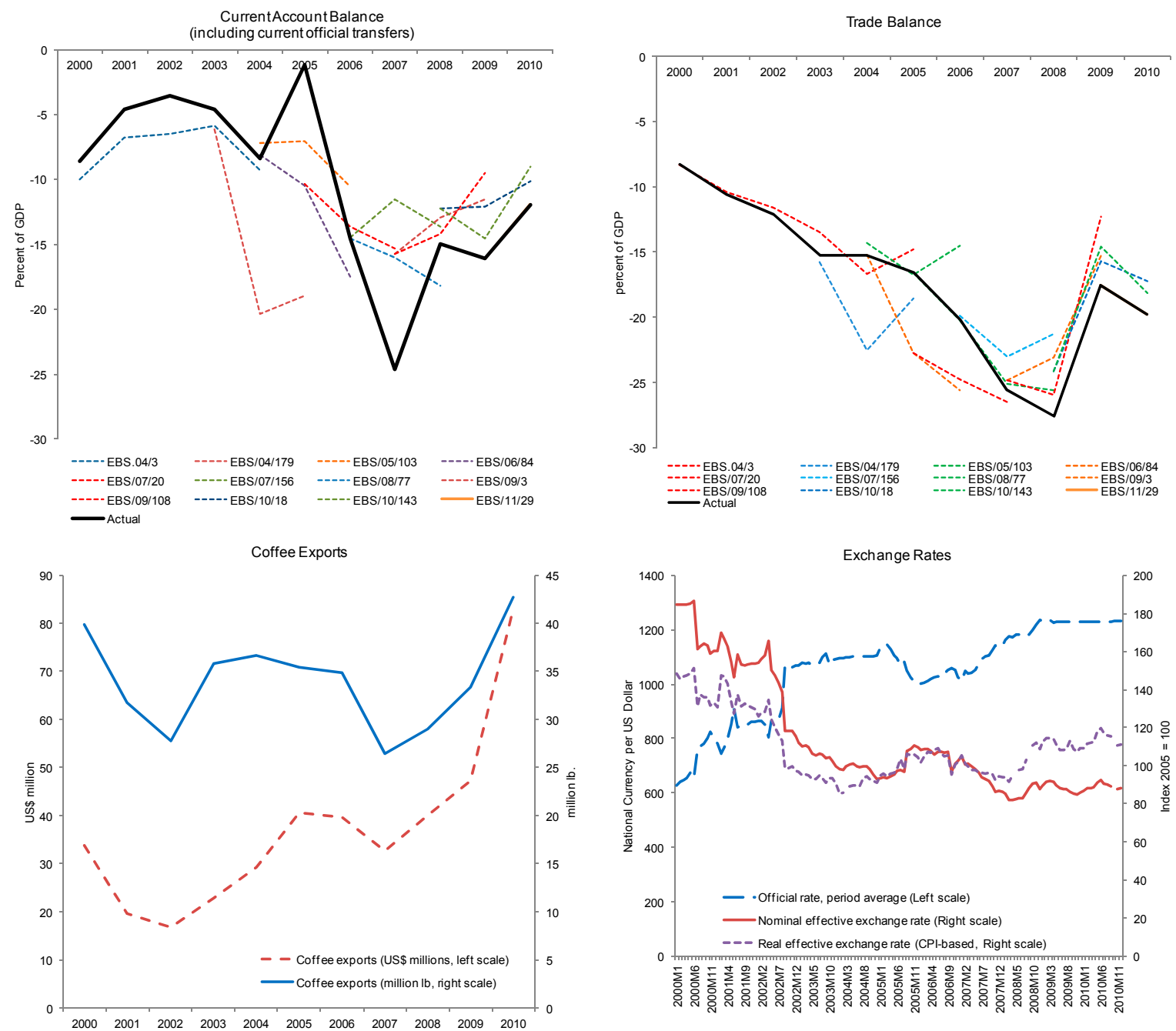
Sources: IMF Country Reports

Source: International Financial Statistics.
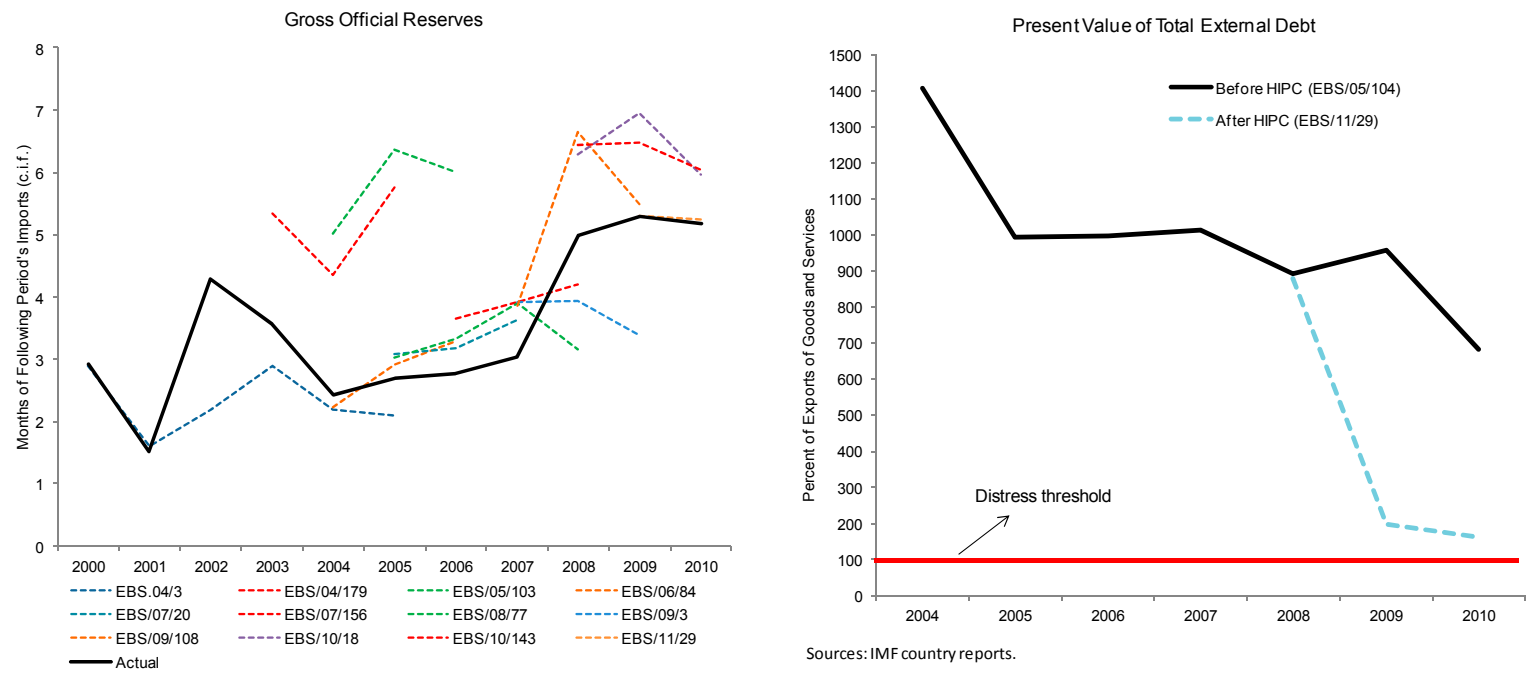


\section{Public finances remained under stress, reflecting the fiscal challenges of peace building, the need to address pressing social and infrastructural needs, and the impact of volatile aid and economic conditions.}

a. Spending the aid: government expansion and persistent deficits. Despite the return of steadier growth and a surge in grants, substantial overall deficit (including grants) persisted, averaging 4.7 percent of GDP over the period (Figure 4). The lack of consolidation and stagnant revenues suggest that the aid surge was fully spent. Deviations between outturns and programmed deficit targets coincided with discrepancies between aid disbursements and commitments and with growth shortfalls, pointing to some flexibility in program targets, particularly during the global recession of 2009. However, expenditure took the bulk of the adjustment to lumpy aid flows, as a majority of grants are project-related and domestic financing sources limited.

b. Expenditure composition. Public finances faced the combined challenge of prioritizing spending on capital projects and social sectors (health and education) and assuming the direct costs of peace building (such as absorbing former rebels into lawful security forces and subsequently implementing an effective and peaceful demobilization). This implied tolerating a rise in military spending to be reversed over time through effective demobilization. A consequence of these policies was a boom in current spending, and in particular, public wage consumption. Between 2005 and 2010, the size of the civil service rose by more than 50 percent, reflecting an initial rise in security forces in 2006 and hiring in priority sectors thereafter. In the meantime, spending on wages and compensations shot up by 80 percent in real terms. The financing of inherently inflexible expenditure with volatile aid flows has made state operations highly vulnerable to aid fluctuations.

c. Mobilizing revenues. As aid dependency puts revenue mobilization at a premium, both programs sought to strengthen and modernize revenue administration. Reforms culminated in 2009 with the creation of an autonomous revenue administration (the Office Burundais des Recettes, OBR) aimed at boosting compliance through a combination of improved taxpayer services, greater transparency, and enhanced audit capacities. In terms of tax reforms, the replacement of an inefficient transaction tax with VAT was a notable achievement. However, results have been slow to materialize, as evidenced by stagnant revenues and serial shortfalls with respect to program forecasts (Figure 4). The first indication of a turnaround in revenue collection emerged in 2010, with a significant windfall attributable to signs of increased compliance under the OBR's first full year of operation and a reduction in tax arrears. However, it is premature to conclude that a structural break in revenue collection took place. 
Figure 4. Burundi: Public Finances (2000-10)

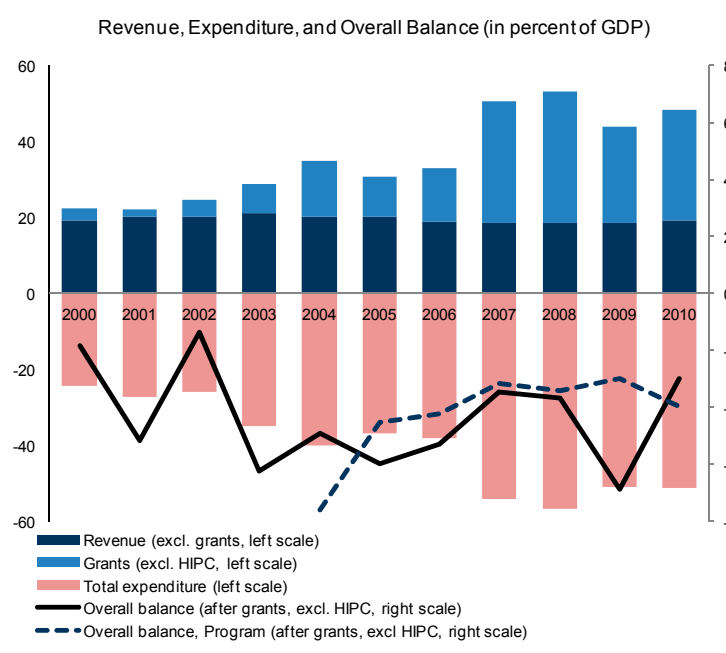

Public Investment (in percent of total spending)

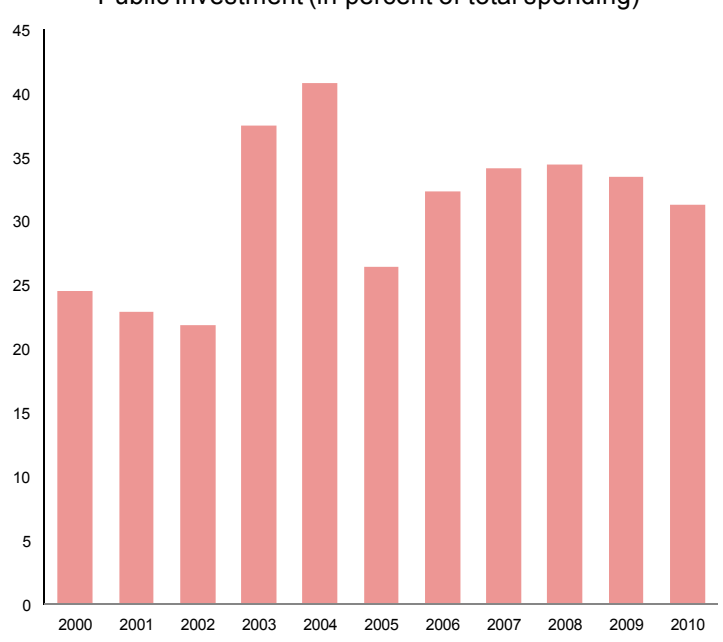

Size of the Civil Service and the Wage Bill

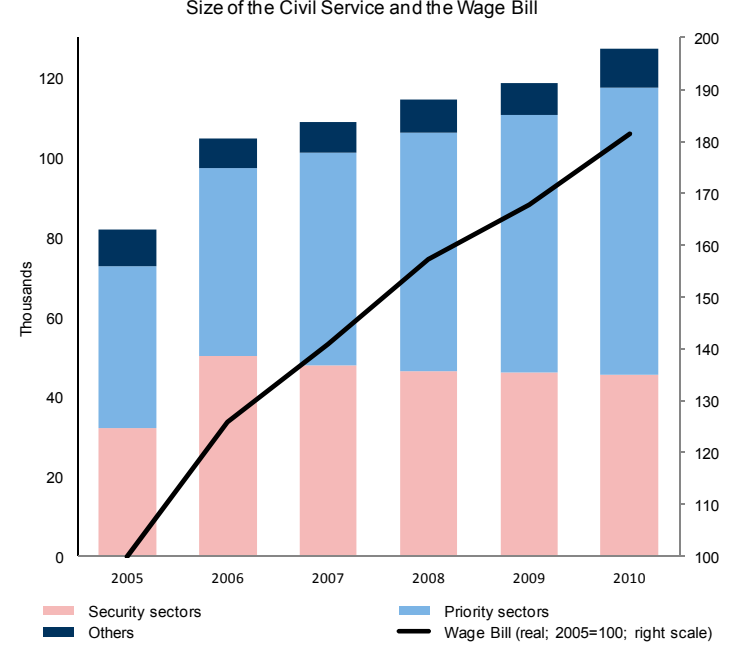

Volatility of Aid and Fiscal Indicators (in percent of GDP)

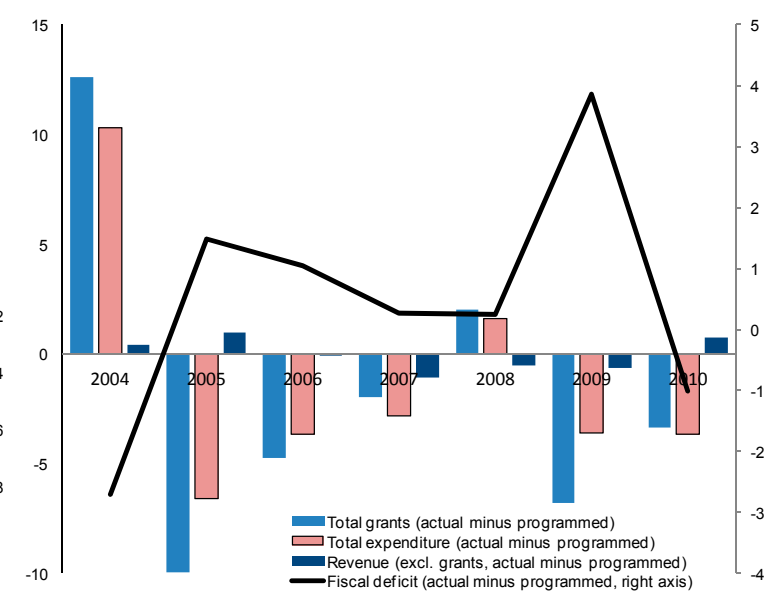

Total Grants and Pro-poor Spending (in million US\$) 1/

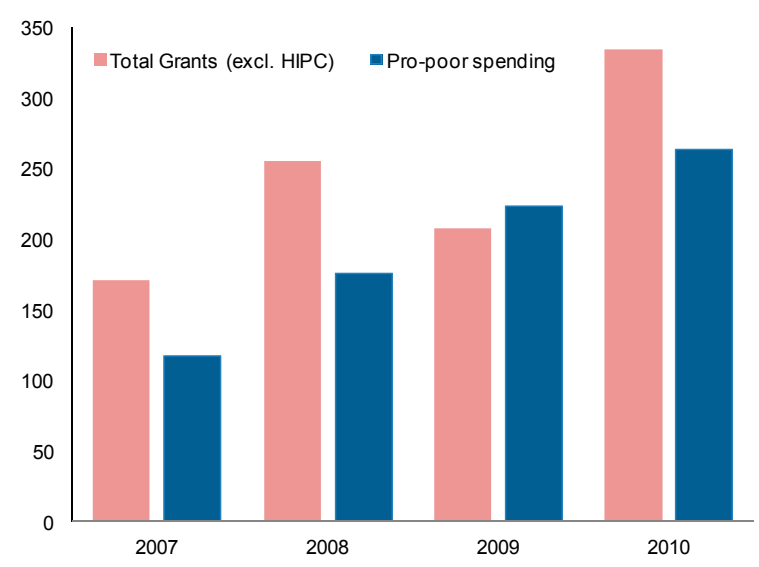

$1 /$ No consistent data available prior to 2007 .

Revenue (excl. Grants) / GDP

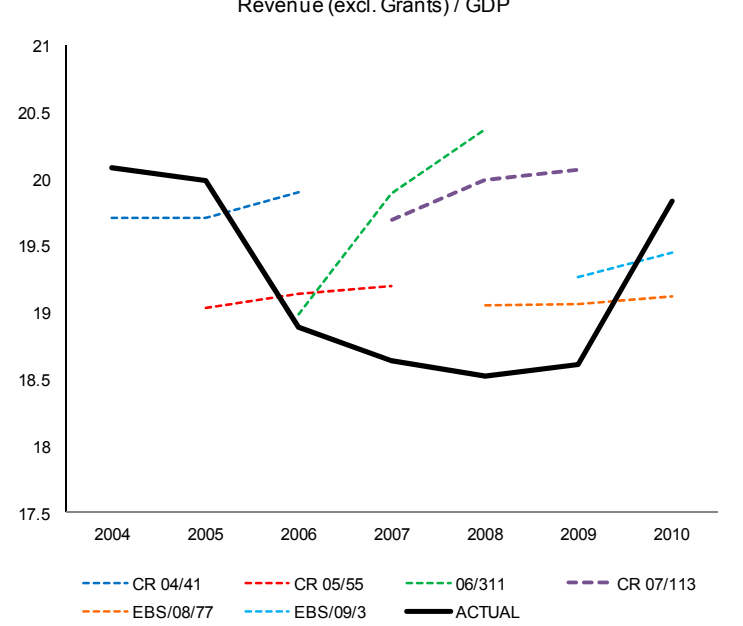

Sources: Burundese authorities and IMF staff calculations. 
d. Public financial management (PFM). As scaled-up aid was absorbed and spent and serious governance issues threatened to undermine donors' confidence, sound PFM has been increasingly perceived as the cornerstone of successful Fund engagement. The very strong focus of the second PRGF/ECF arrangement on PFM issues reflects this concern. Starting from a very low base and with limited capacities, a number of reforms supported by IMF and World Bank TA were enacted to strengthen expenditure planning and execution, and foster transparency and accountability. As a result, large domestic spending arrears were identified and cleared, a court of audit was created, the management of the government workforce was strengthened, a modern budget law was adopted, and a single treasury account was introduced.

\section{Significant progress was made over the period to upgrade monetary} management and financial supervision. While central bank autonomy received additional legal backing, the monetary policy framework was thoroughly modernized through the abolition of credit ceilings, the streamlining (and lowering) of reserve requirements, and the introduction of indirect policy instruments (weekly liquidity auctions, aided by the standardization of treasury bills). However, weaknesses in the conduct of monetary policy remained. Other objectives might have interfered with the pursuit of price stability, whereas liquidity management suffered from the only gradual reform of instruments (e.g., interest rate ceilings were lifted in 2009), the lack of competition among banks (which complicates sterilization operations), and loopholes in the intervention strategy (no monthly and weekly targets consistent with the quarterly program objectives). The

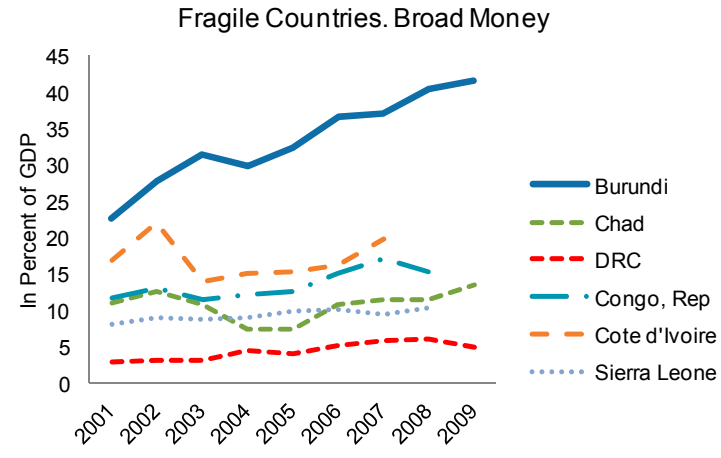
supervision of financial institutions was strengthened and capital requirements were increased. As regards exchange rate determination, the abolition of surrender requirements for traditional exports and of restrictions on current international transactions, as well as the licensing of foreign exchange bureaus considerably narrowed the spread between the official and parallel market exchange rates. These reforms fostered a more rapid monetization of transactions than in other postconflict countries (see figure).

\section{Aside from monetary and fiscal reforms, low capacities and fractious politics} have also complicated efforts to enact other structural reforms that would be essential to unlock growth and dent into poverty. Burundi has endured the legacy of decades of pervasive and inefficient state intervention, calling for a wide array of deep and politically difficult structural reforms. The reform of the coffee sector-coffee is the main source of 
income for half of the population and Burundi's main export - took center stage in the first PRGF, but despite partial progress backed by strong conditionality, ${ }^{5}$ the monopolistic market structure that depresses small producers' income remains largely in place. Reforms in other sectors such as energy and telecommunications are also pursued to help alleviate supply bottlenecks and spur private sector development. Financial development remains very limited: small and medium-sized enterprises face severe credit rationing, mainly because of inadequate information on the credit worthiness of prospective borrowers, the absence of meaningful collaterals, and weak capacity of project preparation and assessment. As noted in the 2009 FSAP, the supply of financial services in Burundi lags behind that of comparable countries. ${ }^{6}$ Improving the business environment is thus urgently needed. The World Bank ranks Burundi among the least business-friendly countries in the world (176 out of 183), and the World Economic Forum as one of the least competitive (137 out of 139), listing poor institutions, lack of skills, financial underdevelopment, and poor market efficiency as the main culprits.

\section{Key social indicators have improved, albeit slowly and from a low base, making} it unlikely that Burundi will reach any Millennium Development Goal (MDG) by 2015. Although a refined assessment of the evolution of poverty and income equality over the period is constrained by data availability, poverty appears to be slowly receding: the multidimensional poverty index ${ }^{7}$ decreased from 0.5 in 2005 to 0.42 in 2009 . The improvement is for the most part driven by remarkable progress in access to education, with a total primary enrollment rate now close to 100 percent (up from 43 percent in 2000 and 63 percent in 2005). Recent government initiatives such as free health care for all children under 5 and care for women in childbirth are also expected to contribute to the population's overall well-being.

\footnotetext{
${ }^{5}$ The ownership of coffee beans has been transferred to farmers and the gradual privatization of coffee washing stations began in 2009, but with only little interest from foreign investors.

${ }^{6}$ With about 4 bank accounts per 1,000 inhabitants, Burundi is below the average for countries such as the Central African Republic (5.6), Uganda (5.8), and Cameroon (14.4).

7 The index takes into account such variables as availability of drinking water, home's roof type, fuel used for cooking, ownership of at least one bicycle, access to electricity, ownership of cattle, and number of people in a house.
} 


\section{The IMF-supported Programs: Design, Assessment AND Lessons}

\section{A. The 2004-08 PRGF Arrangement}

16. The first three-year PRGF arrangement—approved in January 2004—aimed at securing macroeconomic stability, building up confidence, and encouraging structural reforms. Prior to that program (in 2002-03), the authorities had established a track record of policy implementation under an Emergency Post-Conflict Assistance program that was deemed satisfactory. The PRGF arrangement appropriately sought to jumpstart reform dynamics in various critical areas for macroeconomic stability and growth, including monetary stabilization, the liberalization of trade, exchange rate and the financial sector, the strengthening of governance and PFM, and private sector involvement - particularly in the coffee sector.

17. In spite of considerable and well-understood risks, the program succeeded in (i) establishing some of the key foundations of macroeconomic stability; (ii) mobilizing donor resources; and (iii) promoting poverty reduction. Early reforms of monetary policy instruments and exchange rate liberalization created the pre-conditions for the conduct of a stability-oriented policy. Generally satisfactory macroeconomic performance followed, with macro-relevant quantitative performance criteria being met (Appendix 1). As the Fund's engagement reduced the perception of macroeconomic risks and raised expectations of policy stability and consistency, the program played a catalytic role in mobilizing donors' support in financial and TA terms. Flexible fiscal targets allowed for aid to be generally well targeted and fully spent, which likely fostered further donors' involvement. However, the flipside of extensive fiscal flexibility was aid dependency and the absence of consolidation in a context of unsustainable debt. The program also helped achieve steady progress in the HIPC process - in part through conditionality that was well aligned with priorities set out in the PRSPs (Box 1).

\section{Faced with multiple and interlocked policy challenges, the program aimed at} addressing head-on a broad range of macro-critical structural gaps, taking the risk to venture outside the Fund's core expertise. The bulk of structural benchmarks concerned the design and implementation of macroeconomic policies as well as exchange rate and financial liberalization, which all fell clearly in the realm of Fund's expertise and core mandate (Appendix 1). Program conditionality also incorporated key elements of a thorough reform of the coffee sector aimed at breaking state monopolies on the buying and selling sides of the market (Box 2). While a dynamic coffee sector was rightly seen as the key to unlock pro-poor growth in the short-medium term, ${ }^{8}$ conditionality extended its reach in an area where the Fund had neither authoritative expertise nor exclusive mandate.

\footnotetext{
${ }^{8}$ Various studies identified Burundi as an ideal location for growing high-quality coffee, whereas ambitious market-oriented reforms enacted elsewhere provided clear evidence of their positive impact on farmers' income.
} 
19. Despite extensive conditionality tilted toward prior actions, structural reforms remained slow, suggesting saturated capacities and incomplete ownership. Structural performance criteria were frequently waived and structural benchmarks not met, or in a number of instances, were turned into prior actions. The latter were used more frequently than in other fragile or post-conflict countries where the Fund has been engaged (Table 1). Between January 2004 and January 2008, five prior actions and two structural benchmarks concerned coffee sector reform alone. Conditions laid out detailed structural measures such as liberalizing trade and investment, eliminating production taxes, giving farmers a voice in the state marketing agency and reducing its role. While extensive and stringent conditionality likely reflected the urgency of addressing a critical mass of issues to deliver swift macroeconomic stabilization and boost growth, political-economy and capacity constraints might have been underestimated, undermining the traction of conditionality and pointing to incomplete ownership. These mixed results notwithstanding, the coffee sector reform now figures prominently on the authorities' agenda.

\section{Other factors challenged program implementation.}

a. Weak governance tested confidence. Two major governance incidents in 2006 (non-competitive sale of presidential jet) and 2007 (multiple clearance of the same arrears) postponed the completion of the third and last reviews of the program. Staff encouraged and promptly supported satisfactory remedial actions by the authorities, avoiding a potentially damaging unraveling of the program — and with it, of critical donors' confidence and support.

b. Bank-Fund cooperation was difficult in key reform areas, possibly weakening ownership. Between 2004 and 2007, Fund and World Bank staff views on the desirable pace of coffee sector reforms were not well aligned. The Bank favored a succession of partial reforms that would only gradually change the market structure, whereas Fund staff advocated a more transformative approach based on a series of more upfront reforms. The risk perceived by IMF staff was that an overly gradual approach would fail to deliver the "quick wins" needed to build a strong constituency for change. Mixed messages on these important reforms might have complicated the authorities' task to take complete ownership.

c. Essential TA proved difficult to secure in the early phase of the program, when security risks were perceived to be high. Later, the Fund's resident TA advisors (from MCM) contributed to reform implementation and to capacity building. 


\section{Box 1. HIPC Initiative, Poverty Reduction and Debt Sustainability}

The HIPC process was initiated in 2004. A preliminary assessment of Burundi's eligibility for assistance under the enhanced HIPC initiative was made in January 2005 on the basis of (i) heavy debt burden (NPV of debt-to-export ratio estimated to be 1,789 after full application of traditional debt-relief mechanism); (ii) a track record of performance under IDA- and IMF-supported programs; and (iii) Burundi's IDA-only and PRGF eligibility.

The decision point under the enhanced HIPC Initiative was reached in August 2005, and completion point triggers were agreed. Triggers included (i) the preparation of a full Poverty Reduction and Strategy Paper (PRSP) and one year of implementation; (ii) macroeconomic stability evidenced by satisfactory performance under the PRGF-supported program; (iii) allocation of enhanced HIPC Initiative savings to priority spending identified in the interim PRSP; (iv) public expenditure management; (v) governance;

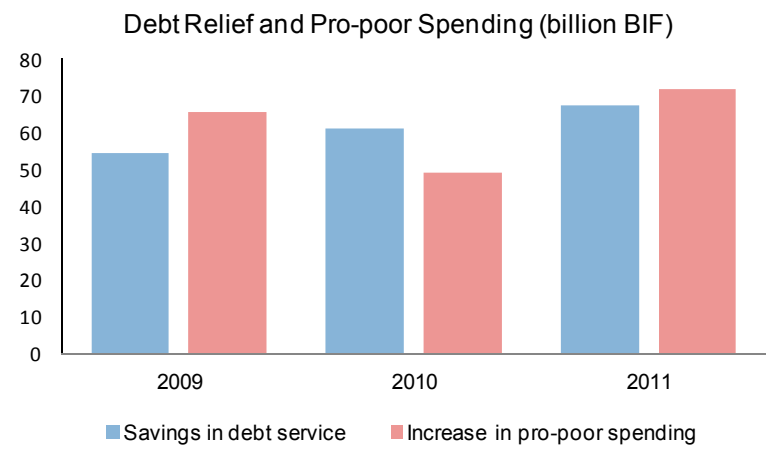

(vi) demobilization; (vii) structural reforms; (viii) key social sectors (health and education); and (ix) debt management.

In September 2006, Burundi adopted its first full PRSP based on (i) refocusing the role of the state to promote the private sector; (ii) maintaining peace and security; (iii) building capacities; (iv) promoting growth; (v) strengthening community involvement; (vi) promoting the role of women; and (vii) establishing a new partnership with donors. Four objectives guided economic and social development programs: good governance; equitable and sustainable growth; development of human capital; and combating HIV/AIDS.

Priorities of Fund-supported programs were well aligned with the PRSP objectives and helped Burundi reach the completion point. The programs were instrumental in preserving macroeconomic stability and facilitated adequate expenditure prioritization, with a direct incidence on the trigger on key social sectors. Reforms on PFM and central bank internal controls - initiated in the first program and leveraged through conditionality in the second program - helped meet the triggers on public expenditure management and governance. The structural-reform trigger - which required tendering for sale of state-owned coffee washing stations - was the object of conditionality during the first program, although full compliance could not be achieved.

The completion point was reached in January 2009. Although triggers on demobilization, the coffee sector, and the social sector had not been fully implemented, World Bank and IMF staff agreed that the completion point should not be delayed. On the coffee sector, full compliance with the trigger was considered to be taking longer because the authorities adopted a more ambitious plan than initially envisaged. Full compliance with the demobilization trigger was not possible because of delayed ceasefire with the last remaining rebel group.

Debt relief created ample space for priority spending. HIPC debt relief was estimated at US\$ 832.6 million in NPV terms at the decision point, about 92 percent of the initial level. Upon reaching the HIPC completion point, Burundi qualified for additional relief of about US\$ 65 million in NPV under the Multilateral Debt Relief Initiative (MDRI). The significant reduction in debt service was associated with corresponding increases in priority spending in 2009-10 (chart). The 2011 budget also considers an increase in pro-poor spending commensurate to debt service relief.

The DSA nevertheless indicates that Burundi is at a high risk of debt distress. The present value of debt-toexports ratio to remain well above the 100 percent threshold throughout the projection period, primarily due to a low export base. Accordingly, performance criteria of the ECF-supported program ban the accumulation of external payment arrears, short-term external debt and non-concessional loans (grant element lower than 50 percent). 


\section{Box 2. Coffee Sector Reform}

State involvement of the coffee sector affects all production stages. Coffee cherries are grown by about 800,000 small producers who either de-pulp harvested coffee cherries manually (washed coffee) or sell cherries to state-run washing stations ${ }^{1}$ (fully washed coffee). The state-owned dry mill company $^{2}$ then buys washed and fully washed coffee to produce green-bean coffee. Finally, a state marketing monopoly sells green-bean coffee to exporters. ${ }^{3}$

This fully monopolistic structure depresses producer prices, discourages private investment, and undermines producers' incentives to aim for high quality coffee. Government intervention can be based on two considerations. The first is to circumvent economy-wide capital scarcity by directing investment to a vital sector. Since fully washed coffee results in higher quality green-bean coffee than washed coffee, technological improvement in the 1980s indeed required significant investment in the washing stations. Second, the state marketing monopoly can in principle shelter producers from world price volatility, especially when prices fall markedly as in the early 1990s. The downsides of such "two-stage" monopolies (where producers face a state monopsony and exporters a state monopoly) are well known: rent is created and captured by the state or its agents, effectively taxing small farmers' income; there is no private incentive to invest - capital scarcity is thus artificially maintained even if it becomes less problematic in the economy at large-and producers have no motivation to move to higher quality because the resulting rent is likely to be captured by the state. Not surprisingly, the share of high quality coffee in total output decreased continuously during the 1990s from 70 percent to about 10 percent.

Despite evidence of successes in other countries, reforms in Burundi have been repeatedly delayed since the 1990s. Reforms are of course intrinsically difficult in politically and socially fragmented environment which requires more than elsewhere particular attention to proper sequencing, transparency, and consensus building. All this takes time. By the HIPC completion point in January 2009, all the major stakeholders including the authorities at the highest level endorsed the need for restructuring the sector, and the coffee sector trigger (tendering for sale the state holdings in a majority of coffee washing stations) was substantially implemented. Full compliance took longer because of the more extensive nature of the reforms envisaged by the authorities, leading to a waiver request.

However, beyond social considerations and political economy-constraints, a successful reform of the coffee sector seems to hinge crucially on an improved investment climate. The difficult privatization of 13 coffee washing stations (less than 10 percent of the total) in 2009 may signal the reluctance of private investors to engage in an environment where the perception of weak governance, inconsistent policies and dubious commitments creates uncertainty. Success with coffee sector reform thus also depends on resolute progress in broader confidence- and efficiency-enhancing measures, including strengthened governance, streamlined tax and regulatory systems, better infrastructure and an effective financial sector. As such, it is bound to be gradual and to remain at risk of reversal until a critical mass is reached, as indicated by fresh delays in launching the second phase of washing stations privatization and vocal opposition of well-organized vested interests.

1 They are managed by five state- and mixed-ownership management companies SOGESTALS (Sociétés de Gestion des Stations de Lavage).

${ }^{2}$ SODECO (Société de Déparchage et de Conditionnement).

${ }^{3}$ OCIBU (Office des Cultures Industrielles du Burundi). 
Table 1. Conditionality per review: Burundi Relative to other PRGF/ECF Supported Programs

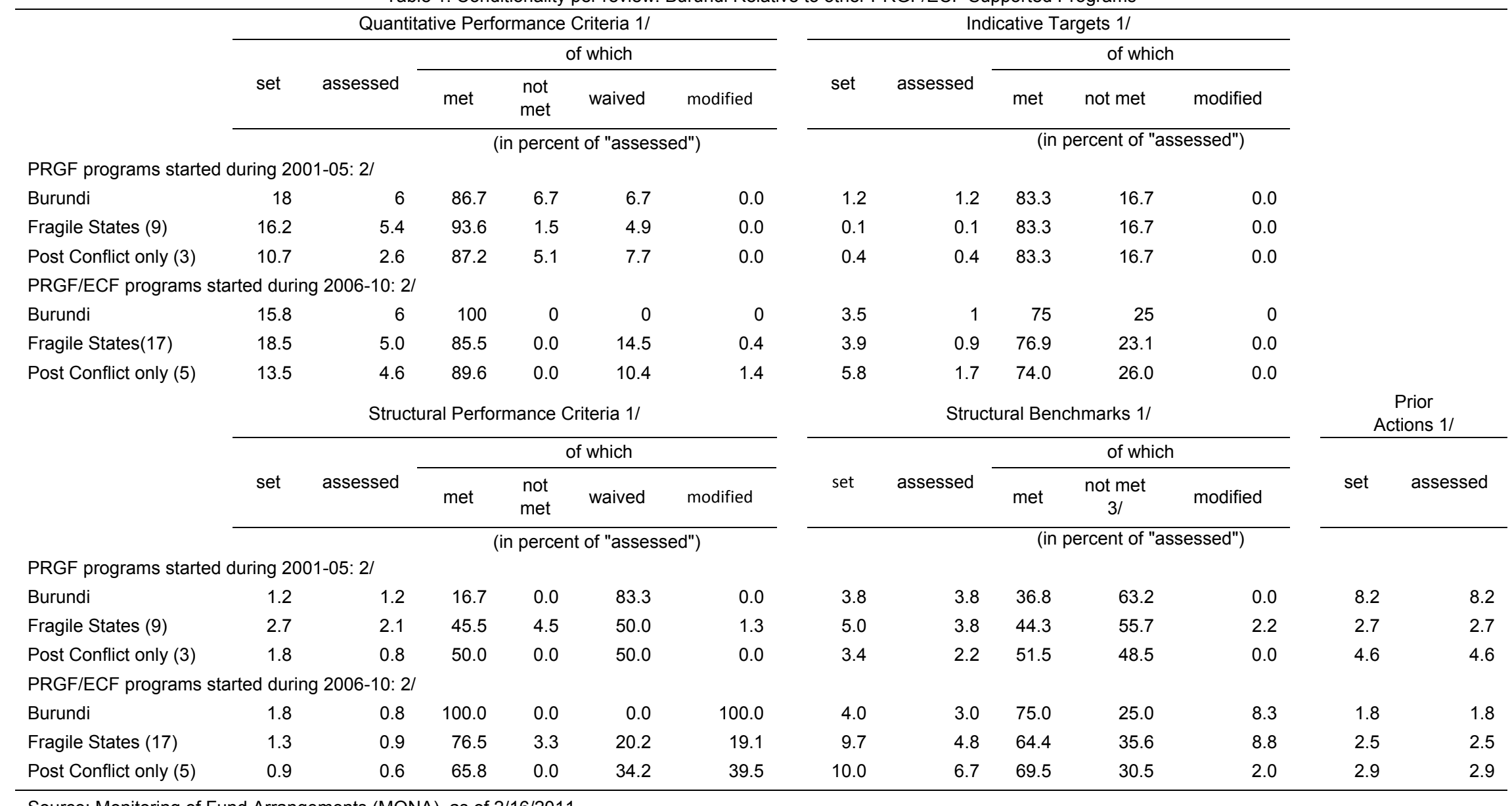

Source: Monitoring of Fund Arrangements (MONA), as of 2/16/2011.

1/ "Set" and "assessed" are in average number of conditionalities per review; "met," "not met," "waived," and "modified" are in percent of conditionalities assessed.

2/ For the classification of fragile and post-conflict states, the World Bank's "Harmonized List of Fragile Situations FY11" is used.

Numbers in ( ) indicate the number of arrangements used to compute the average number of conditionalities per review.

3/ Also includes "met with delay" and "partially met." 


\section{B. The 2008-11 PRGF/ECF Supported Program}

\section{Approved in July 2008, the second three-year PRGF/ECF arrangement focused} on consolidating and furthering the main achievements of the first PRGF arrangement. The program specified objectives deemed achievable over a three-year horizon in light of the existing capacities, the successes of the first program, and the urgent gaps to address. The stated goals are single-digit inflation, fiscal sustainability, greater quality of public spending, stronger PFM and governance, and tighter central bank internal controls. While staff reaffirmed the criticality of deep structural reforms and closely monitored progress, the program abstracted from setting any binding target in these areas, leaving leadership to the World Bank.

\section{The structural-fiscal objectives of the program have been largely met, but} progress toward meeting other goals has been slower, in part due to exogenous shocks.

a. Fiscal and monetary flexibility in response to shocks. Despite the global crisis and exogenous price shocks, all quantitative performance criteria have so far been met, reflecting significant flexibility of fiscal targets in the face of the global crisis and the corresponding needs to adjust domestic credit ceilings to the largerthan-expected budget gap. As discussed in Section II, stabilizing inflation in the program's target zone has remained challenging due to food and energy price shocks.

b. Fiscal sustainability still at risk. Even though Burundi reached the HIPC completion point in January 2009—obtaining considerable debt relief—debt sustainability remains a serious concern. Yet the program limits itself to restrict external debt financing to highly concessional loans, with no clear medium-term consolidation objectives aimed at gradually aligning own resources with spending needs. Recent improvements in the fiscal balance are encouraging to the extent that they reflect efficiency gains in revenue administration.

c. Despite the program's considerable emphasis on increasing social outlays, improving the quality of public expenditure remains a challenge. The program actively promoted a shift of public resources away from the wage bill and into items with a well-defined poverty-reduction impact. To that end, indicative targets were set, with dubious effectiveness. A ceiling on the wage bill was repeatedly exceeded, owing to the difficulty to bring down security spending sufficiently rapidly in light of the needed hiring in social sectors. Staff supported a delay in more ambitious demobilization until after the 2010 elections, given the sensitivity of the matter. At the third review, a floor on "pro-poor spending" was introduced and generally exceeded.

d. Furthering structural fiscal reforms. Despite some delays, a substantially streamlined reform agenda focused on PFM and fiscal transparency has been achieved. In particular, the budget law and fiscal accounting have been upgraded; a 
modern tax administration has been established - in close coordination with a large bilateral donor-and budget execution has improved steadily.

e. The central bank's internal controls have been strengthened. Building on the 2004 safeguards assessment and recommendations from external audits by an international firm, areas considered critical for preventing misreporting and safeguarding Fund resources were strengthened, including the bank's external audit mechanism, the financial reporting framework, and internal controls.

23. Structural conditionality was extremely parsimonious, but appropriately focused on public finances, and supported by strong $\mathbf{T A}$, which helped internalize and address capacity constraints and enhance ownership. In sharp contrast with the first PRGF arrangement, structural conditionality was materially lighter (in number and stringency) than in other contemporaneous programs in fragile or post-conflict countries, reflecting in part a strict focus on tax reform, PFM and the financial sector (Table 1). Prior actions were limited to an initial push to promptly address fiscal management and transparency issues exposed by the governance incidents. All subsequent structural benchmarks were met, sometimes with delays. The need to tackle serious governance gaps, and the importance of ensuring the effectiveness of scaled-up aid clearly made the PFM focus macro-critical with potentially strong positive spillovers to other policy areas and the broader business climate. Other macro-critical reforms were not subject to any Fund conditionality and left entirely to the World Bank. Focus and parsimony in conditionality as well as a clear delineation of responsibilities between the Fund and the World Bank reduced the risk of overwhelming the country's capacities. In addition, program implementation greatly benefitted from more intensive and timely TA than under the first PRGF arrangement, particularly in the fiscal sector, where a resident advisor was pivotal in distilling actionable advice in the field and maintaining continuous dialogue with the authorities and other donors. Finally, good cooperation with the World Bank helped advance the structural reform agenda, including the privatization of a first batch of coffee washing stations.

\section{Lessons}

24. Despite sharp differences in design and elevated risks, both programs met key objectives, illustrating the importance of early full-fledged engagement and of flexibility in program implementation. Both programs - especially the first PRGF - faced dynamic political and economic environments making "first-best" considerations - such as the specific definition of the objectives and conditionality - less critical for success than in other contexts. Burundi's experience indeed shows that the effectiveness of Fund engagement in a fragile and risky environment lies in the ability to devise a workable "second-best" as events unfold and binding constraints are revealed in the field. This entails a combination of built-in flexibility of the program — through the use of adjusters and/or focused conditionality — and a 
problem-solving mindset - as opposed to orthodox thinking. ${ }^{9}$ This relatively fluid approach to program design and implementation facilitated an early engagement with a full-fledged PRGF that contributed to macroeconomic stabilization and a rapid increase in aid.

\section{Although multiple and interdependent reforms are needed, structural conditionality should internalize capacity constraints and the centrality of ownership.} Limited capacities call for focusing on technically simple reforms with large spillovers and visible impact ("quick wins"), and for parsimony in the use of conditionality. In addition, the fractious politics that often characterize fragile countries imply that only gradual strategies can realistically be consistent with ownership. Burundi's experience illustrates these points. The first PRGF arrangement sought and obtained quick wins in monetary and financial matters, but failed to promote the much more complex reform of the coffee sector. Although the program adequately internalized capacity constraints by breaking down the reform into a series of simpler actions backed by specific conditionality, the reform was not fully owned and stalled. The second PRGF arrangement strictly refocused on the Fund's core expertise and was effectively supported by TA, allowing for a much lighter conditionality. Three lessons emerge. First, a focused conditionality does not necessarily imply the targeting of a single area of reforms, but could include simple, high-impact measures in various sectors relying on different pools of skills. Second, in a low-capacity context, parsimony should not be interpreted in an overly narrow "numerical" sense (e.g., "no more than $x$ structural benchmarks per review") because of the likely need to decompose a given measure into a coherent set of technically simple and easily monitored actions whose adequate sequencing may benefit from conditionality backing. Third, no matter how well specific conditions are designed and capacity constraints internalized, they cannot substitute for the lack of ownership.

26. Strong coordination among development partners is vital. Ideally, coordination should go beyond the clear sharing of responsibilities achieved at the end of the first program and continued thereafter, and imply a shared vision and mutually reinforcing actions. In particular, it is important to secure the World Bank's support ${ }^{10}$ in macro-critical areas that lie outside the Fund's core mandate. Vice-versa, Fund conditionality in areas where other donors play a leading role remains an option to help committed authorities to overcome temporary obstacles to reform.

\section{Well-coordinated TA coming at an early stage, aligned with program priorities} and involving field presence is critical to success. In fragile contexts with very low

\footnotetext{
${ }^{9}$ The accommodation of a large but temporary increase in military outlays, traditionally classified as "unproductive," illustrates this problem-solving approach.

${ }^{10}$ The support of bilateral donors can also be useful. For instance, during the first PRGF, a large bilateral donor agreed to condition its disbursements to demobilization targets aligned on the Fund's.
} 
capacities, TA goes well beyond tailored policy advice anchored in international best practice. To be effective, a critical mass of TA has to be delivered early, and it should entail capacity building, outreach to decision makers and other donors, and continuous efforts to develop concrete, actionable recommendations. As Burundi's experience shows, resident TA advisors are uniquely placed to fulfill these roles and maintain permanent contact with the authorities and other donors to limit the risk of overlap and inconsistencies among providers. 


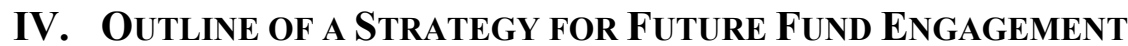

\section{After two largely successful IMF-supported programs, there is a strong case for} the Fund to remain engaged in Burundi. Fund engagement has been instrumental in encouraging macroeconomic stability, fostering policy credibility, attracting aid, and building up capacities. However, the very low income base and a still uncertain growth takeoff suggest that Burundi is likely to remain strongly dependent on external support, in which Fund engagement plays a catalytic and stabilizing role. The need to boost private sector development and attract foreign investors - not just donors - also argues in favor of continued Fund support because of the additional credibility it lends to economic and financial policies. Finally, the Fund's TA and policy advice, in close cooperation with donors, would remain essential to strengthen institutions and capacities. A successor ECF would provide an adequate framework.

\section{The future program should retain a strong emphasis on enhancing PFM,} boosting revenue mobilization, and accelerating tax reforms. Very pronounced aid dependency calls for preserving donors' confidence and firmly anchoring their expectations (Figure 5). It is therefore important to continue to improve governance, building on the recent progress in the PFM and revenue administration areas. Greater transparency and controls along the expenditure chain would increase confidence in the effectiveness of aid and the absorptive capacities of the authorities. Fiscal transparency would also reduce the risk of governance incidents prone to trigger sudden stops in external assistance. The authorities could be encouraged to adopt anti-corruption mechanisms in line with international best practice. ${ }^{11}$ Progress on revenue mobilization would provide strong signals of the government's ability to use the growth dividends to progressively align domestic resources with public spending needs (sustainability) and preserve a socially sustainable income distribution (inclusiveness). Burundi has lagged behind other countries in terms of revenue mobilization and has therefore a significant reservoir to tap into to reduce aid dependency (Figure 5). Finally, pending tax policy reforms should be implemented promptly. In particular, the income tax should be simplified in line with EAC harmonization guidelines and TA recommendations, and the exemption regime should be streamlined.

30. Resolute action is needed to improve the quality of public spending. Efforts to shrink the budgetary footprint of the wage bill should receive high priority. Burundi absorbs an exceptionally large share of domestic resources for public sector pay (Figure 5). However, any conditionality in that area should avoid broad-based caps, as this could lead to unwarranted wage moderation — which prevents the retention of skilled staff — or undue constraints on priority sectors to avoid politically sensitive cuts in security personnel. Overall caps could also encourage the development of nonwage compensations. Eventual program

\footnotetext{
11 The United Nations Convention against Corruption—ratified by Burundi—lists such mechanisms.
} 
conditionality aimed at changing expenditure composition could usefully focus on marginal spending allocations rather than total spending composition to reflect the needed gradualism and enhance the policy's visibility.

31. A successor program should strike the right balance between reforms narrowly aimed at improving the conduct of macroeconomic policies and other macro-critical reforms. Specifically, the Fund could more actively support measures that relax binding constraints to growth, including financial sector development, for instance by encouraging the emergence of an effective interbank market, improving the payment system and promoting access to credit and other banking services, especially for SMEs - a key engine of homegrown growth (see figure). In that regard, the 2009 FSAP report recommended the introduction of a comprehensive clearing and settlement infrastructure, especially for small payments; improvements in the legal framework for businesses, including bankruptcy law, arbitration, and judiciary efficiency; and enhanced

Burundi. Greatest impediments to doing business (percent of survey respondents)

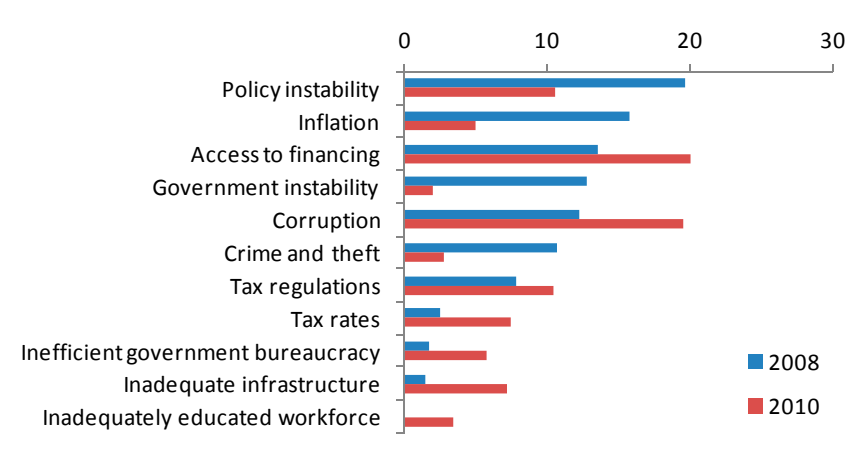

Sources: World Economic Forum, Global Competitiveness Reports (2008 and 2010). accounting standards. The Fund could therefore engage with other donors - and especially the World Bank - to explore the potential contribution of conditionality to progress in key sectors, such as coffee, where the authorities have voiced a strong commitment. Trade and financial integration with other EAC countries also creates a momentum for important, fullyowned reforms that might require specific Fund support, particularly in the form of TA (Box 3).

\section{Ensuring public debt sustainability should remain a key program objective and} requires an explicit consolidation strategy. As debt relief was insufficient to ensure sustainability, the return of steadier growth combined with enhanced institutional capacities to mobilize revenues offer an opportunity to devise a medium-term consolidation strategy at a low social cost. Specifically, saving a reasonable share of the own revenue gains related to growth and better tax administration could secure a steady improvement in the budget balance (including grants), while leaving the shock-absorbing role of the budget intact. Over time, stronger budget positions would tame concerns about long-term aid dependency. Additional gains could come from addressing persistent weaknesses in debt management.

\section{As the incidence of external shocks is unlikely to abate over a typical program} horizon, attention should be paid to a better balanced policy mix in response to shocks. While built-in fiscal flexibility remains essential in an environment where few have access to credit, the burden of stabilization to external shocks could be better shared with monetary policy. This requires greater exchange rate flexibility. While the de facto shadowing of the 
US dollar has some advantages in terms of financial and monetary stability, there is certainly scope for letting the exchange rate absorb some of the terms of trade shocks. To preserve the nominal anchorage of the currency, moving towards greater exchange rate flexibility will require a clearer focus of monetary policy on price stability, further improvements in liquidity management, and continued liberalization of the capital account in the context of EAC integration.

\section{Conditionality should remain commensurate to capacities and limited to areas} where the authorities' commitment is clear. As in the previous and current programs, quantitative performance criteria should remain few and focused on credit and fiscal aggregates. Regarding structural reforms, the new framework for review-based conditionality provides welcome flexibility in the time frame for the implementation of difficult measures, avoiding the pitfall of setting artificial test dates. In general good ownership should also allow for parsimonious and light conditionality. However, in areas where vested interest could test the authorities' resolve - e.g., in agriculture - more binding conditions might be required provided that they remain consistent with the authorities' commitments. Finally, the broad range of structural impediments affecting economic performance calls for a reasonably flexible interpretation of the notions of focus and parsimony. In particular, the Fund should not hesitate to introduce conditionality in macro-critical areas where other donors take the lead - such as the privatization of the coffee industry - provided that conditionality is supported or encouraged by the leading donor and that it concerns fully owned reforms. In addition, capacity constraints call for carefully designing conditions that are achievable and on the basis of which unambiguous action can be taken. As discussed earlier, this may entail a greater number of conditions.

\section{Securing TA deemed critical for program implementation will remain vital. In} the monetary and financial areas, EAC integration will be an important catalyst requiring intense and coordinated efforts form the Fund and other donors. On the fiscal side, TA will need to be focused on the implementation of recent legislative PFM reforms, tax policy changes, and on building capacities. In both areas, there is an overwhelming case for ensuring permanent field presence.

\section{Risks to the new program are likely to remain high, but experience shows that}

they are manageable. The two programs under review have demonstrated the importance of flexibility when (economic or political) risks materialize. A practical and problem-solving approach will thus remain essential. As implementation risks also arise from weak capacities, strong coordination with other donors would be important to avoid counterproductive overlaps (notably in TA delivery) and capacity saturation, and to secure adequate prioritization and sequencing of the many needed reforms. 
Figure 5. Burundi: Selected Cross-Country Comparisons

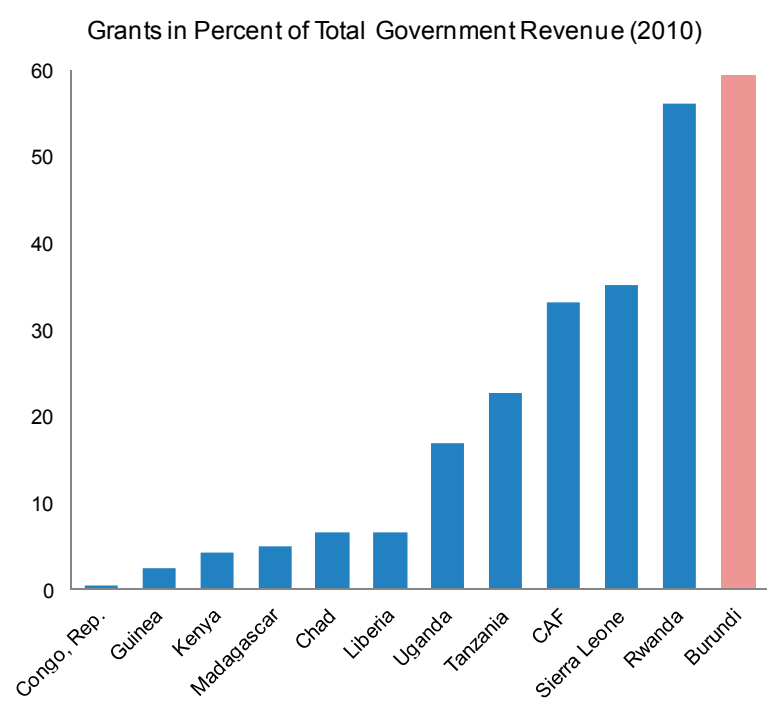
Fragile Countries - Wage Bill in Percent of Revenue (excl. grants), Average 2008-2010
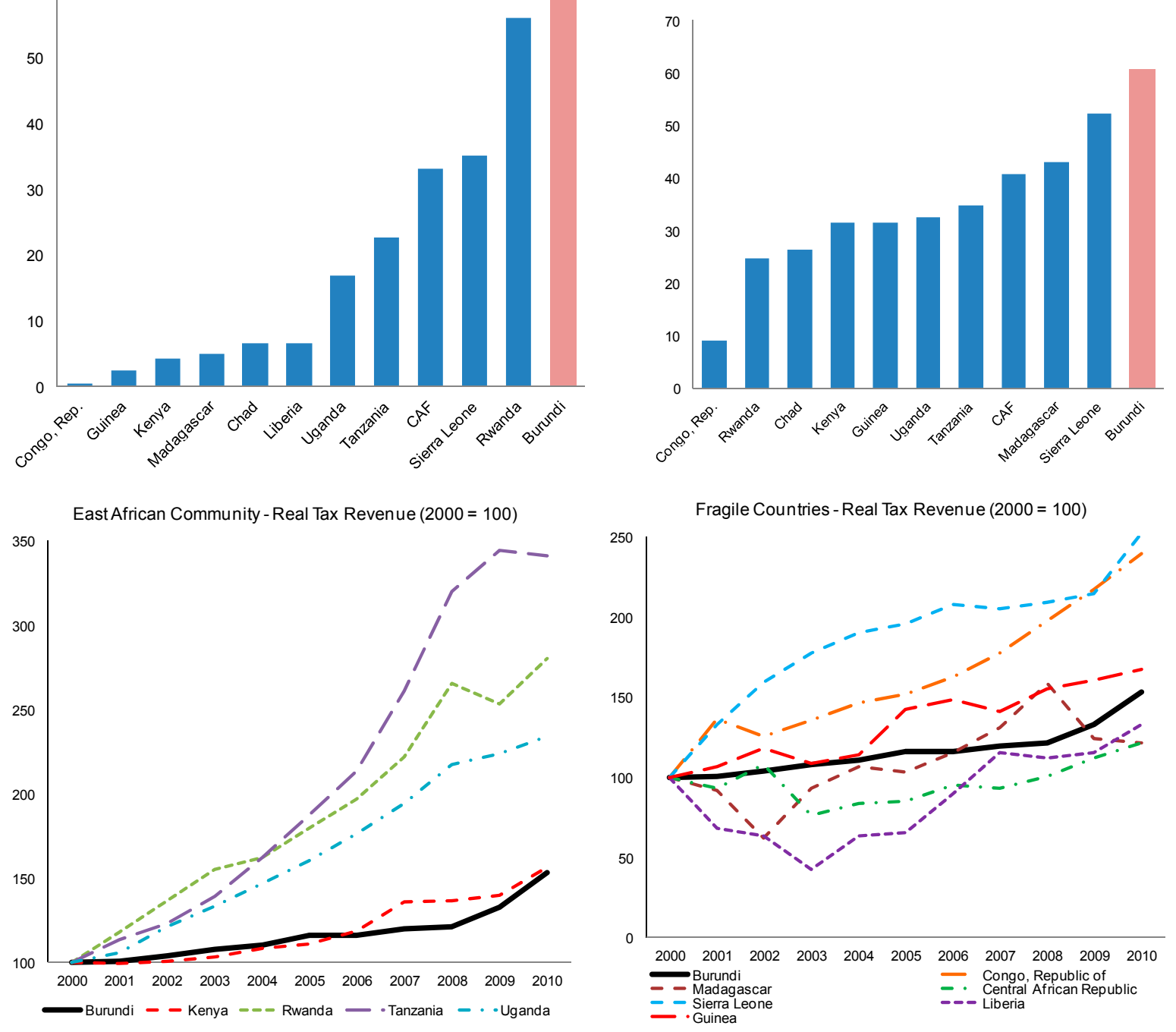

Sources: World Economic Outlook. 


\section{Box 3. East African Integration: A Game Changer?}

Burundi joined the East African Community (EAC) in 2007. The Community, established in 2000 by Kenya, Tanzania, and Uganda, also comprises Rwanda. The objectives of the EAC are to deepen cooperation among member states in political, economic, and social matters. To that end, member countries formed a customs union in 2005 and a common market in 2010. The next stages in regional integration are the formation of a monetary union (planned for 2012), and ultimately, the creation of a political federation. The EAC has a population of about 127 million, a GDP of 73.8 billion dollars (2009), a land area of 1.8 million square kilometers, and a broad access to sea through Kenya and Tanzania.

Regional integration could help Burundi ease some important constraints to growth. First, a well-functioning common market would give Burundi access to a bigger market and lower overseas shipment costs, increasing the attractiveness of the country for foreign investors, especially in sectors where a distinct comparative advantage may be exploited, such as highquality coffee and other agricultural goods. Second, regional integration could also help Burundi take advantage of economies of scale, while spurring domestic market efficiency through greater competition. Third, a regional anchor can foster progress in key policy areas, including economic and financial regulations, and promote policy credibility and predictability.

Yet regional integration by itself is not a panacea. Experience with the European Union shows that members starting from a low base need strong policies and ambitious reforms early on to avoid being trapped in a diverging periphery. Regional integration will expose the private sector (including banks) to greater competition from more developed EAC countries. This will require the rapid implementation of measures aimed at boosting local businesses capacity to compete and create jobs. According to private sector surveys, limited access to financing, pervasive corruption, and inadequate public policies (tax, infrastructure, high and volatile inflation, bureaucratic inefficiency) are the main obstacles to business development (World Economic Forum, 2011).

Hence, to reap the full benefits of ECA integration Burundi will need to (i) further enhance macroeconomic policy credibility; (ii) improve public sector management by promoting accountability, transparency, and efficiency; (iii) encourage financial sector development; (iv) invest beyond primary education to ease the shortage of skilled labor; (v) simplify the tax and regulatory environments; and (vi) alleviate infrastructure bottlenecks. This would help the country benefit fully from greater market access by putting it in conditions to diversify its export base and move toward higher value-added products, and by strengthening institutional and absorptive capacities.

Efforts toward policy and legal harmonization have accelerated in recent years, culminating with the establishment of a common market in July 2010. This prompted Burundi to replace a transaction tax with a modern VAT system and to adopt the EAC's common external tariff. Going forward, TA in a wide range of topics (e.g., monetary policy, financial stability, payment system, financial market development) will be needed to help the authorities harmonize their policies to those of the EAC in areas such as trade regulation, competition policy, labor laws, energy policies, and central bank independence. 
Table 2. Burundi: Selected Economic and Financial Indicators, 2004-11

$\begin{array}{lllllll}2004 & 2005 & 2006 & 2007 & 2008 & 2009 & 2010\end{array}$

2011

Proj.

\begin{tabular}{|c|c|c|c|c|c|c|c|c|}
\hline National income and prices & \multicolumn{8}{|c|}{ (Annual percentage change) } \\
\hline Real GDP growth & 4.8 & 0.9 & 5.1 & 3.6 & 4.5 & 3.5 & 3.9 & 4.2 \\
\hline GDP deflator & 8.3 & 16.6 & 4.4 & 8.2 & 25.1 & 14.1 & 7.8 & 11.9 \\
\hline Consumer prices (period average) & 8.0 & 13.4 & 2.8 & 8.3 & 24.4 & 10.7 & 6.4 & 8.2 \\
\hline Consumer prices (end of period) & 11.8 & 1.0 & 9.3 & 14.7 & 25.7 & 4.6 & 4.1 & 14.0 \\
\hline \multicolumn{9}{|l|}{ External sector } \\
\hline Exports, f.o.b. (US\$) & 27.5 & 19.5 & 2.6 & -9.7 & 15.1 & 21.5 & 37.7 & 3.9 \\
\hline Imports, f.o.b. (US\$) & 16.1 & 27.6 & 28.7 & 20.6 & 26.5 & -19.6 & 42.9 & 23.0 \\
\hline Export volume & -10.9 & -1.7 & -7.6 & -1.7 & 0.4 & 16.0 & 10.8 & -22.8 \\
\hline Import volume & 3.9 & 16.4 & 10.3 & 6.0 & 12.7 & 6.3 & 4.9 & -1.6 \\
\hline Terms of trade (deterioration $=-$ ) & 28.1 & 10.9 & -4.9 & -23.4 & 2.1 & 38.5 & -8.7 & 7.6 \\
\hline & \multicolumn{8}{|c|}{$\begin{array}{l}\text { (Change in percent of beginning of period M2, } \\
\text { unless otherwise indicated) }\end{array}$} \\
\hline \multicolumn{9}{|l|}{ Money and credit } \\
\hline Net foreign assets & -4.1 & 15.9 & 1.7 & 11.5 & 21.9 & -2.9 & -5.4 & -0.7 \\
\hline Domestic credit & 39.8 & -0.4 & 29.6 & 6.6 & 18.8 & 27.8 & 24.2 & 17.7 \\
\hline Government & 34.8 & 7.2 & 14.4 & -0.2 & 5.8 & 17.1 & 6.6 & 3.9 \\
\hline Private sector & 5.0 & -6.7 & 13.7 & 7.6 & 8.5 & 13.7 & -3.6 & 13.8 \\
\hline Money and quasi-money (M2) & 16.7 & 27.1 & 16.4 & 10.1 & 34.2 & 19.8 & 19.4 & 14.2 \\
\hline Reserve money (12-month growth rate) & 37.2 & 32.7 & 5.9 & 17.4 & 25.1 & 26.6 & 6.0 & 12.3 \\
\hline \multirow{2}{*}{\multicolumn{9}{|c|}{ General government }} \\
\hline & & & & & & & & \\
\hline Revenue (excluding grants) & 20.1 & 20.0 & 18.9 & 18.6 & 18.5 & 18.6 & 19.8 & 19.4 \\
\hline Total expenditure and net lending & 39.8 & 36.8 & 38.2 & 38.5 & 56.7 & 50.7 & 54.7 & 47.4 \\
\hline \multicolumn{9}{|l|}{ Overall balance (commitment basis) } \\
\hline Excluding grants & -19.7 & -16.8 & -19.3 & -19.8 & -38.2 & -32.1 & -34.9 & -28.0 \\
\hline Including grants (excl. HIPC) & -4.9 & -6.3 & -1.8 & -3.3 & -2.4 & -5.2 & -3.2 & -3.1 \\
\hline \multicolumn{9}{|l|}{ External sector } \\
\hline Current account balance & -8.1 & -1.2 & -14.5 & -15.7 & -15.0 & -16.1 & -13.4 & -16.5 \\
\hline Overall balance of payments & 1.7 & 4.5 & 1.4 & 3.1 & 7.4 & 4.1 & 0.9 & -1.2 \\
\hline Savings-investment balance & -8.1 & -1.2 & -14.5 & -15.7 & -15.0 & -16.1 & -13.4 & -16.5 \\
\hline Private & 5.6 & 5.1 & -12.7 & -12.4 & -12.6 & -10.9 & -10.1 & -13.4 \\
\hline \multirow[t]{2}{*}{ Public } & -13.7 & -6.3 & -1.8 & -3.3 & -2.4 & -5.2 & -3.2 & -3.1 \\
\hline & \multicolumn{8}{|c|}{ (US\$ million, unless otherwise indicated) } \\
\hline \multirow{2}{*}{\multicolumn{9}{|c|}{$\begin{array}{l}\text { External sector } \\
\text { Gross official reserves }\end{array}$}} \\
\hline & & & & & & & & \\
\hline US\$ million & 67.2 & 112.7 & 131.0 & 177.3 & 267 & 323 & 332 & 319 \\
\hline Months of imports & 2.2 & 3.0 & 3.3 & 3.8 & 5.0 & 5.0 & 4.8 & 4.7 \\
\hline Debt-service to exports ratio (percent) & 99.8 & 28.4 & 11.1 & 6.8 & 3.2 & 1.7 & 1.2 & 6.9 \\
\hline \multicolumn{9}{|l|}{ Memorandum item: } \\
\hline GDP at current market prices (BIF billion) & 732 & 861 & 945 & 1060 & 1386 & 1637 & 1833 & 2137 \\
\hline
\end{tabular}

Sources: Burundi authorities; and IMF staff estimates and projections. 


\section{Appendix 1. Conditionality}

Overview of Structural Conditionality of Burundi PRGF Arrangement (January 2004-January 2008)

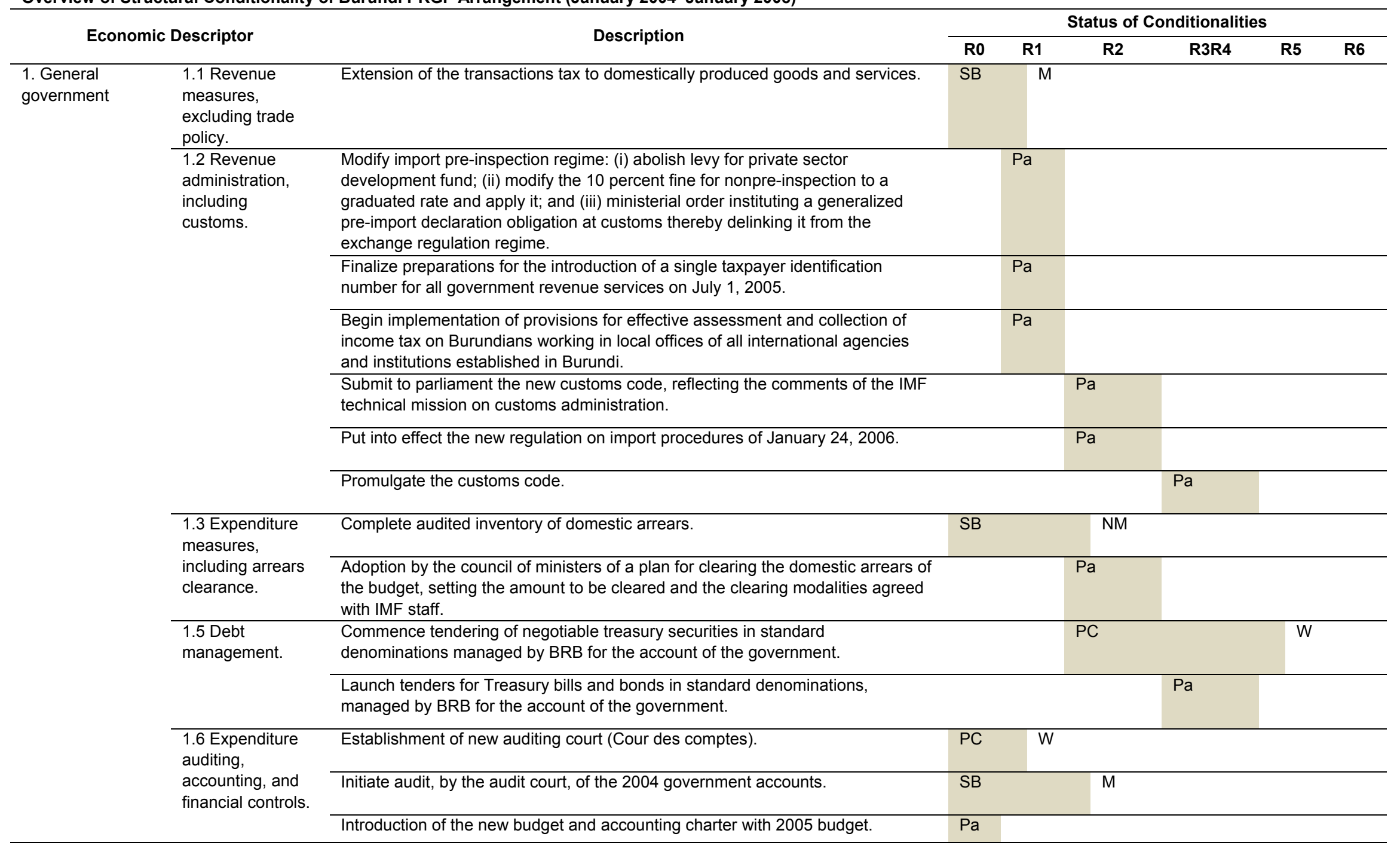




\begin{tabular}{|c|c|c|c|c|c|c|c|}
\hline \multirow{2}{*}{ Economic Descriptor } & \multirow{2}{*}{ Description } & \multicolumn{6}{|c|}{ Status of Conditionalities } \\
\hline & & Ro & R1 & $\mathbf{R 2}$ & R3R4 & R5 & R6 \\
\hline & $\begin{array}{l}\text { Submission to parliament of law on statute of magistrates of the audit court (Cour } \\
\text { des comptes). }\end{array}$ & $\mathrm{Pa}$ & & & & & \\
\hline & $\begin{array}{l}\text { Reinforce civil service wage bill management through the posting of a budget } \\
\text { control unit at the ministry of the civil service to monitor wage bill commitments } \\
\text { and payments. }\end{array}$ & & $\mathrm{Pa}$ & & & & \\
\hline & Passage by parliament of a law on the status of magistrate of the audit court. & & $\mathrm{Pa}$ & & & & \\
\hline & $\begin{array}{l}\text { Install a computerized financial management information system (IFMIS) of } \\
\text { moderate size in the Ministry of Finance, with the link to the BRB, designed to } \\
\text { monitor budget implementation (notably social spending), and produce summary } \\
\text { fiscal tables. }\end{array}$ & & PC & & W & & \\
\hline & $\begin{array}{l}\text { Integrate the Budget payroll in the Integrated Finance Management Information } \\
\text { System (IFMIS). }\end{array}$ & & & $\overline{\mathrm{PC}}$ & & $\mathrm{MD}$ & \\
\hline & $\begin{array}{l}\text { Establishment of a single data file for the computerized management of the } \\
\text { payroll at the Ministry of Finance. }\end{array}$ & & & & $\mathrm{PC}$ & & $\mathrm{W}$ \\
\hline & $\begin{array}{l}\text { Creation of a unit attached to the office of the Ministry of Finance, responsible for } \\
\text { the monitoring and coordination of public finance reforms. }\end{array}$ & & & & $\mathrm{Pa}$ & & \\
\hline & Issue decree transferring payroll management to the Ministry of Finance. & & & & $\mathrm{Pa}$ & & \\
\hline & $\begin{array}{l}\text { Establishing an exhaustive list of the kinds of expenditures that may be made } \\
\text { without a prior payment order (ordonnancement). }\end{array}$ & & & & & $\mathrm{Pa}$ & \\
\hline & Launch an external audit of HIPC expenditures. & & & & & $\mathrm{Pa}$ & \\
\hline & $\begin{array}{l}\text { Ministerial Orders of the Ministry of Finance concerning the status and } \\
\text { prerogatives of the internal control office in the Ministry of Finance, and the } \\
\text { duties of the office responsible for developing the IFMS. }\end{array}$ & & & & & $\mathrm{Pa}$ & \\
\hline & Clarifying the provision of Article 52 of the Public Accounting law. & & & & & $\mathrm{Pa}$ & \\
\hline & $\begin{array}{l}\text { Launch an external audit of cross-debts between the petroleum sector and the } \\
\text { budget. }\end{array}$ & & & & & $\mathrm{Pa}$ & \\
\hline $\begin{array}{l}1.7 \text { Fiscal } \\
\text { transparency }\end{array}$ & Publication of the audit court's report of the 2004 government accounts. & & SB & & NM & & \\
\hline 1.8 Budget & Presentation of 2005 budget to parliament consistent with program objectives. & $\mathrm{Pa}$ & & & & & \\
\hline & Adoption by parliament of a budget law for 2004 in line with program objectives. & $\mathrm{Pa}$ & & & & & \\
\hline
\end{tabular}




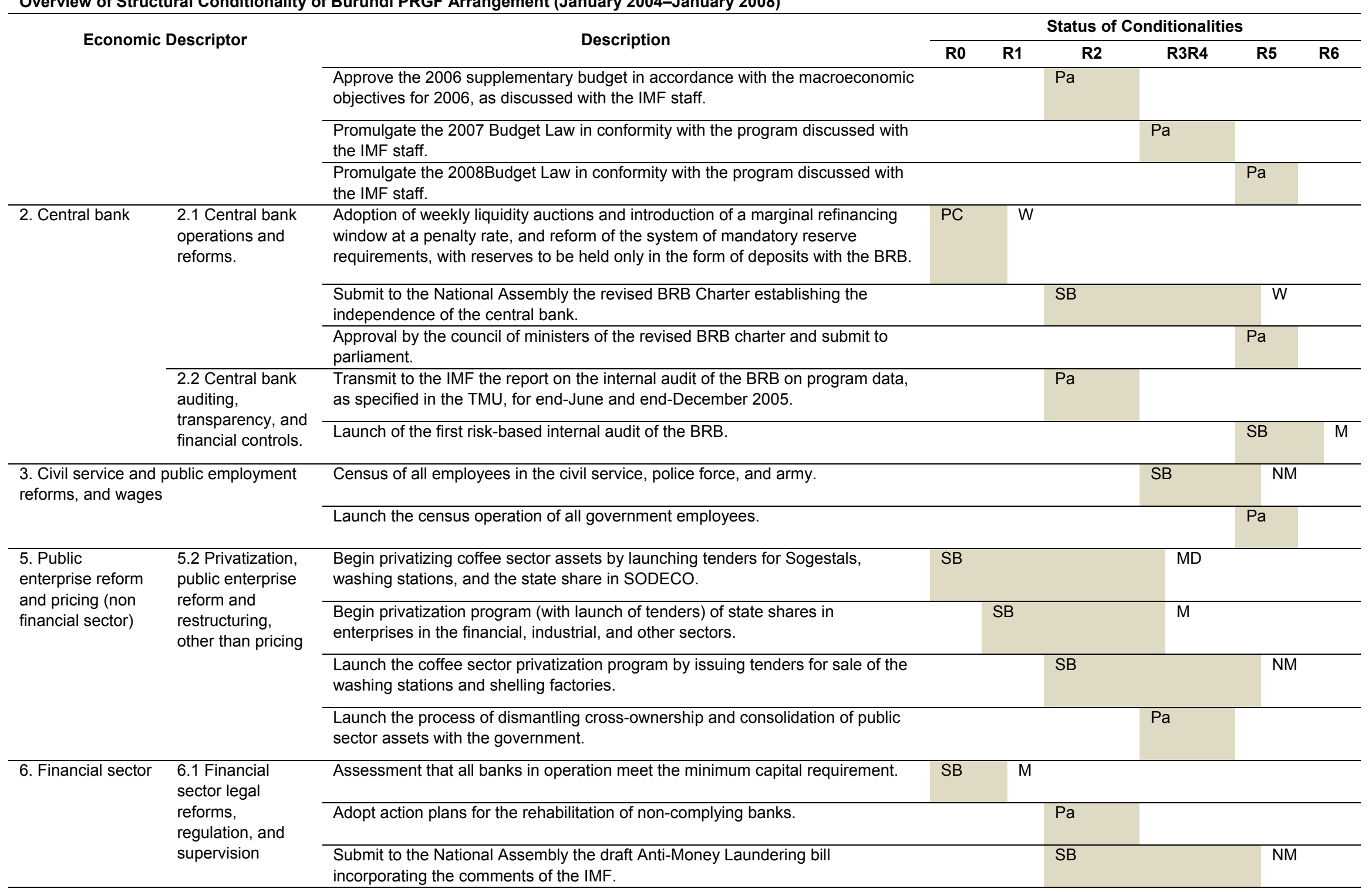




\begin{tabular}{|c|c|c|c|c|c|c|c|c|}
\hline \multirow{2}{*}{\multicolumn{2}{|c|}{ Economic Descriptor }} & \multirow[b]{3}{*}{$\begin{array}{l}\text { Approval by council of ministers of the draf } \\
\text { keeping with IMF staff recommendations. }\end{array}$} & \multicolumn{6}{|c|}{ Status of Conditionalities } \\
\hline & & & \multirow[t]{2}{*}{ Ro } & \multirow[t]{2}{*}{ R1 } & \multirow[t]{2}{*}{$\mathbf{R 2}$} & R3R4 & R5 & \multirow[t]{2}{*}{ R6 } \\
\hline & & & & & & $\mathrm{Pa}$ & & \\
\hline & & Parliament passage of the anti-money laundering law. & & & & & $\mathrm{Pa}$ & \\
\hline \multirow{3}{*}{\multicolumn{2}{|c|}{$\begin{array}{l}\text { 7. Exchange systems and restrictions } \\
\text { (current and capital) }\end{array}$}} & $\begin{array}{l}\text { Elimination of all remaining exchange restrictions on current account transactions } \\
\text { and bona fide amortization payments. }\end{array}$ & $\mathrm{Pa}$ & & & & & \\
\hline & & $\begin{array}{l}\text { Abolish remaining export surrender requirement (50 percent of coffee, tea, and } \\
\text { cotton exports receipts). }\end{array}$ & & PC & $\mathrm{M}$ & & & \\
\hline & & Adopt and publish the single exchange system regulation. & & & SB & $\begin{array}{l}\text { NM/P } \\
\text { a }\end{array}$ & & \\
\hline \multicolumn{2}{|c|}{$\begin{array}{l}\text { 8. International trade policy, excluding } \\
\text { customs reforms }\end{array}$} & Lift trade restrictions and price controls on sugar. & SB & & & $\mathrm{M}$ & & \\
\hline \multirow{4}{*}{\multicolumn{2}{|c|}{$\begin{array}{l}\text { 10. Economic statistics (excluding fiscal } \\
\text { and central bank transparency) }\end{array}$}} & $\begin{array}{l}\text { Adopt officially, and include in the PRSP, the development plan for statistics } \\
\text { prepared by the IMF Statistics Mission in March } 2006 .\end{array}$ & & SB & & & MD & \\
\hline & & $\begin{array}{l}\text { Approval by the council of ministers of a new institutional framework for } \\
\text { ISTEEBU and a new code for ISTEEBU employees that will allow them hence to } \\
\text { produce, without interrupting the principal macroeconomic indicators. }\end{array}$ & & SB & & & NM & \\
\hline & & Submission to parliament of the draft statistics law. & & & $\mathrm{Pa}$ & & & \\
\hline & & Approve the implementing regulations for the statistics law. & & & & $\mathrm{Pa}$ & & \\
\hline \multirow[t]{6}{*}{$\begin{array}{l}\text { 11. Other } \\
\text { structural } \\
\text { measures }\end{array}$} & $\begin{array}{l}11.1 \text { Private } \\
\text { sector legal and } \\
\text { regulatory } \\
\text { environment } \\
\text { reform (non } \\
\text { financial sector) }\end{array}$ & $\begin{array}{l}\text { Ministry of Commerce order abolishing the list of SOSUMO sugar wholesalers } \\
\text { and establishing the freedom to operate for wholesalers on the basis of set } \\
\text { technical criteria. }\end{array}$ & & SB & $\begin{array}{l}\text { NM/P } \\
\text { a }\end{array}$ & & & \\
\hline & \multirow{5}{*}{$\begin{array}{l}11.2 \text { Natural } \\
\text { resource and } \\
\text { agricultural } \\
\text { policies (excl. } \\
\text { public enterprises } \\
\text { and pricing) }\end{array}$} & $\begin{array}{l}\text { Issue decree for the liberalization of coffee sector marketing and trade at all } \\
\text { levels of the production chain. }\end{array}$ & SB & & $\mathrm{M}$ & & & \\
\hline & & Abolish the "loyer verger" on coffee sector producers. & & $\mathrm{Pa}$ & & & & \\
\hline & & Publish ministerial order on the freedom of direct sales in the coffee sector. & & $\mathrm{Pa}$ & & & & \\
\hline & & $\begin{array}{l}\text { Adopt an action plan defining the new roles of coffee sector institutions (including } \\
\text { OCIBU) to be in place for the start of the } 2006 \text { crop season (April 2006), } \\
\text { consistent with coffee sector reform strategy. }\end{array}$ & & SB & & NM & & \\
\hline & & $\begin{array}{l}\text { Establish a committee for the coordination and monitoring of the coffee sector } \\
\text { reform, with terms of reference, objectives, and operational modalities. }\end{array}$ & & & $\mathrm{Pa}$ & & & \\
\hline
\end{tabular}




\begin{tabular}{|c|c|c|c|c|c|c|c|}
\hline \multirow{4}{*}{ Economic Descriptor } & \multirow{2}{*}{ Description } & \multicolumn{6}{|c|}{ Status of Conditionalities } \\
\hline & & Ro & R1 & R2 & R3R4 & R5 & R6 \\
\hline & Abolition of the technical commissions of OCIBU. & & & $\mathrm{Pa}$ & & & \\
\hline & $\begin{array}{l}\text { Reform the marketing committee of OCIBU to include representatives of all } \\
\text { operators in the coffee sector. }\end{array}$ & & & $\mathrm{Pa}$ & & & \\
\hline
\end{tabular}

Note: M: met; MD: met with delay; NM: not met; W: waived; Pa: prior action; SB: structural benchmark; PC: performance criterion. 
Overview of Structural Conditionality of Burundi PRGF Arrangement (July 2008-July 2011)

Economic Descriptor

Status of Conditionalities

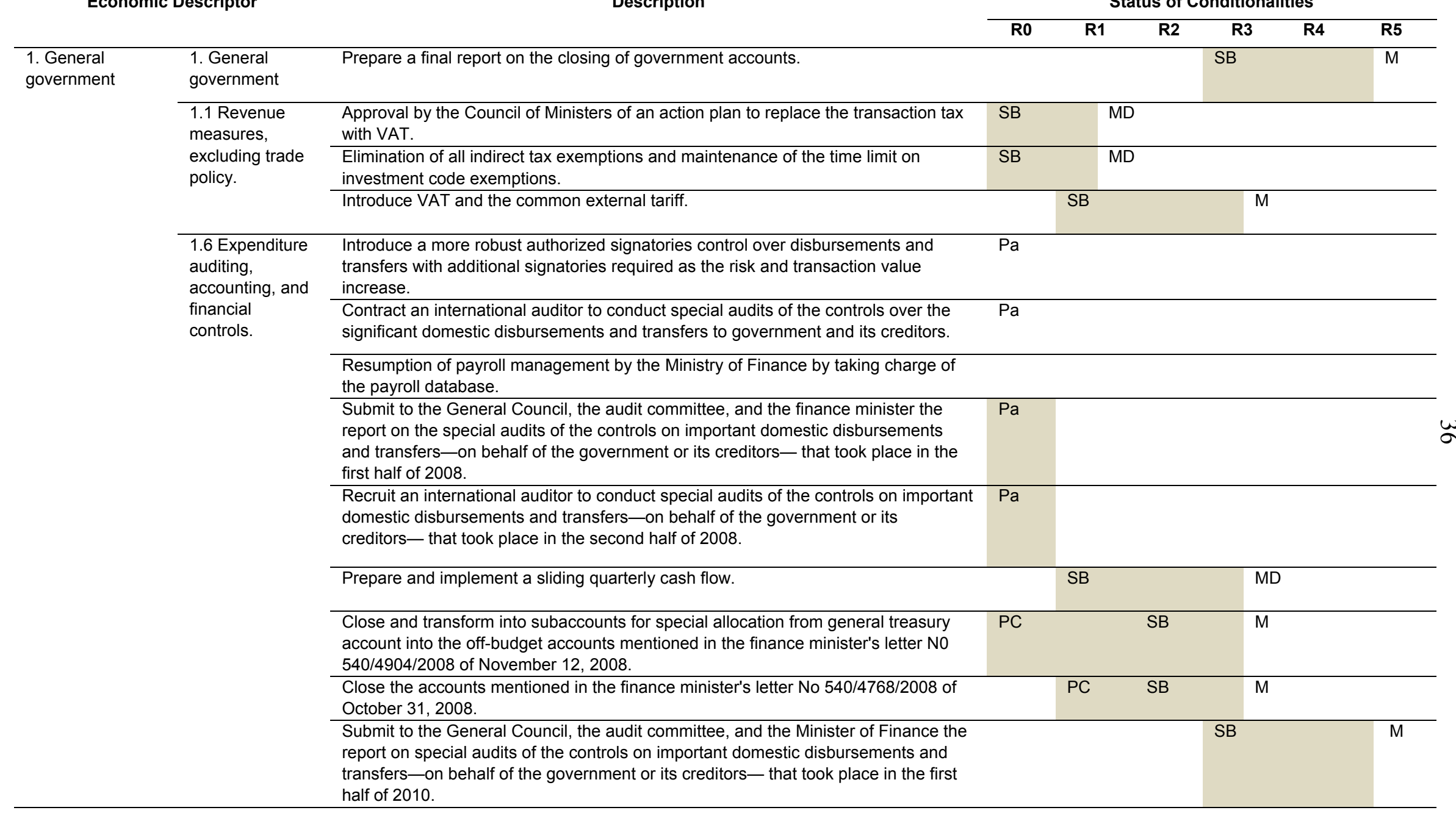




\begin{tabular}{|c|c|c|c|c|c|c|c|c|}
\hline \multicolumn{2}{|c|}{ Economic Descriptor } & \multirow[t]{2}{*}{ Description } & \multicolumn{6}{|c|}{ Status of Conditionalities } \\
\hline & & & RO & R1 & $\mathbf{R 2}$ & R3 & R4 & R5 \\
\hline & & $\begin{array}{l}\text { Recruit an international auditor to (i) monitor the full implementation of all the } \\
\text { recommendations formulated in Deloitte's } 2008 \text { special audit reports (consistent with } \\
\text { the September } 2009 \text { agreed-upon action plan between Burundi's central bank and } \\
\text { the Ministry of Finance); and (ii) verify on a test basis the controls on significant } \\
\text { domestic disbursements and transfers executed by the central bank on behalf of the } \\
\text { government or its creditors during the first half of } 2010 \text {. }\end{array}$ & & & & SB & M & M \\
\hline & $\begin{array}{l}1.7 \text { Fiscal } \\
\text { transparency }\end{array}$ & $\begin{array}{l}\text { Publication of the audit report on cross-debts between the government and the oil } \\
\text { sector. }\end{array}$ & $\mathrm{Pa}$ & & & & & \\
\hline & $\begin{array}{l}1.8 \text { Budget } \\
\text { preparation }\end{array}$ & Submission to the National Assembly of the draft new budget Organic Law. & $\mathrm{Pa}$ & & & & & \\
\hline & $\begin{array}{l}1.9 \text { Inter- } \\
\text { governmental } \\
\text { relations }\end{array}$ & $\begin{array}{l}\text { Adopt a new "convention" between the Ministry of Finance and the BRB redefining } \\
\text { the role of the central bank in PFM, as stipulated under the new budget Organic } \\
\text { Law. }\end{array}$ & & & & SB & & M \\
\hline 2. Central bank & $\begin{array}{l}2.1 \text { Central bank } \\
\text { operations and } \\
\text { reforms. }\end{array}$ & $\begin{array}{l}\text { Submission to the National Assembly of the draft Law on the Charter of the BRB } \\
\text { together with the January } 2008 \text { recommendations by Fund staff on improvement of } \\
\text { the law. }\end{array}$ & $\mathrm{Pa}$ & & & & & \\
\hline \multirow{2}{*}{\multicolumn{2}{|c|}{$\begin{array}{l}\text { 3. Civil service and public employment } \\
\text { reforms, and wages }\end{array}$}} & Start of the police and army census. & SB & M & & & & \\
\hline & & Completion of the census of all government civil employees. & PC & M & & & & \\
\hline $\begin{array}{l}\text { 11. Other } \\
\text { structural } \\
\text { measures }\end{array}$ & $\begin{array}{l}11.4 \text { Anti- } \\
\text { corruption } \\
\text { legislation/policy }\end{array}$ & $\begin{array}{l}\text { In accordance with the laws of Burundi, the FBu } 6 \text { billion and the deeds for } 25 \\
\text { properties belonging to Interpetrol that have been placed under seal will remain in } \\
\text { place until a court decision has been reached on the Interpetrol case. }\end{array}$ & $\mathrm{PC}$ & & SB & & & NM \\
\hline
\end{tabular}

Source: Monitoring of Fund Arrangements (MONA).

Note: M: met; MD: met with delay; NM: not met; W: waived; Pa: prior action; SB: structural benchmark; PC: performance criterion. 
Overview of Quantitative Performance Criteria of Burundi PRGF/ECF Arrangements

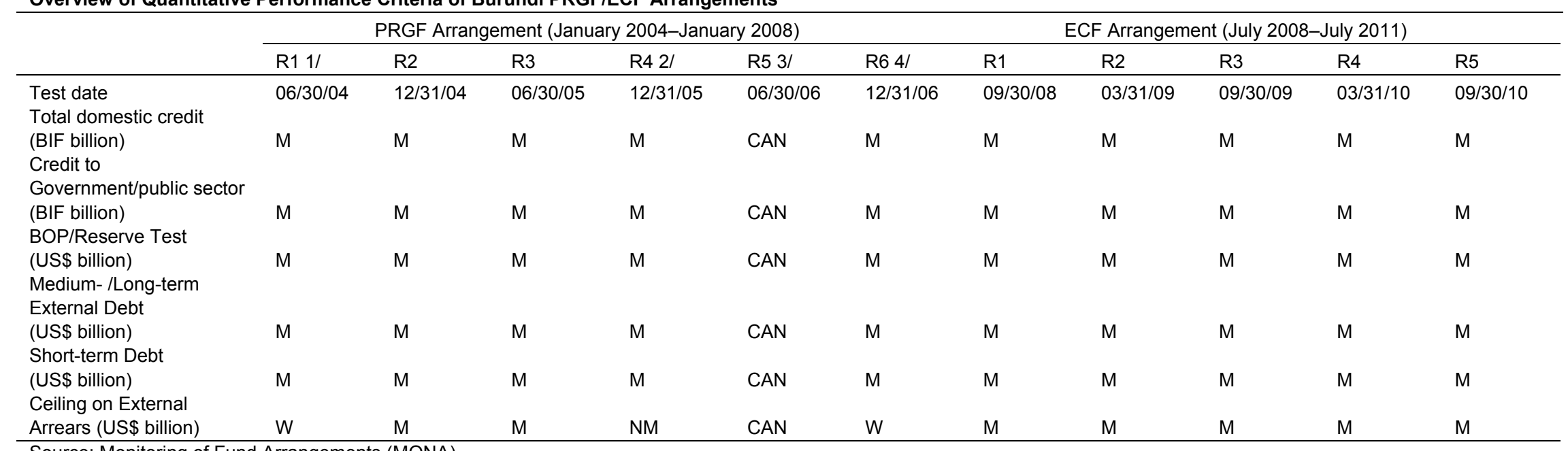

Source: Monitoring of Fund Arrangements (MONA).

Note: M: met; NM: not met; W: waived; CAN: canceled; PC: performance criterion.

1/ R1, an upward revision of the historic stock of arrears estimated at the time when the 2004 program was designed and slower arrears clearance were the causes of exceeding the ceiling. Corrective action was taken and a waiver approved.

2/ At R4, no waiver requested for the temporary accumulation of external payment arrears to OPEC Fund in late 2005, which had since been cleared.

3/ At R5, test date changed to indicative target observation.

4/ At R6, waiver granted for the temporary accumulation of external payment arrears, which was cleared in January 2007. 


\section{Appendix 2. Authorities' Views}

The authorities broadly agreed with the analysis, the conclusions, and the recommendations of the report regarding the main features of a possible successor arrangement. They made the following comments for clarification and emphasis.

\section{On the Ex-post Analysis and the Lessons}

Despite Fund staff flexibility in the implementation of the programs, the first PRGF arrangement suffered from a lack of ownership and a weak participation of the government in the design of the program. Conditionality was sometimes imposed rather than negotiated. It is particularly unfortunate that some measures - although economically sound and likely beneficial in the long term - have been imposed without properly taking into account the broader political-economic context. For instance, the elimination of certain food subsidies during a difficult wage bargaining round was particularly untimely. So was the insistence to accelerate demobilization of military personnel before a complete return to peace. That said, significant progress - described in the report - has been made in a number of areas, for the good of Burundi's economy and despite the magnitude and the multiplicity of the challenges combined with a fragile political environment and a still uncertain peace.

Government's involvement in the design of the program has steadily increased over the period. During the last two reviews of the second ECF arrangement, the government took full responsibility in drafting of the letter of intent and the memorandum of understanding.

Technical assistance played an important role in accompanying reforms - especially in the public sector - and, to a lesser extent, in building up capacities. However, a critical mass of TA could only be reached quite late. Moreover, precious time was wasted in multiple and overlapping diagnostic missions leaving government staff with only general recommendations that were not easily implementable. It is therefore essential for TA providers to follow up on their recommendations, ideally through the presence of a resident expert or more regular visits. Future TA should also include a significant training component and focus on facilitating the effective implementation of reforms across the various sectors.

As indicated in the report, donor coordination is essential. In particular, it would be useful for the Fund to engage with other multilateral donors well before the final negotiation of the program, so as to ensure its internal consistency.

\section{On the Recommendations}

The report could have noted that government contribution to the program would be greater if discussions were expanded to line ministries concerned by the specific measures under consideration. 
The wage bill — even though it is too large — still exhibits the stigmata of the transition to peace (and the corresponding increase in security forces), and reflects the execution of past commitments on wage increases. Civil service reform is of course needed, but it is only part of the solution. First, in the short-term, a peaceful demobilization requires accompanying measures that entail costs for the budget. Second, it should be clear that the solution to an oversized wage bill also involves growth acceleration and improved revenue mobilization.

As indicated in the report, a future program should incorporate an explicit growth acceleration strategy elaborated in close cooperation with the World Bank. Growth demands massive private and public investment. These elements should be an integral part of Fund staff's dialogue with the government, implying a great deal of flexibility in the face of largescale projects deemed essential to alleviate growth bottlenecks. This is particularly relevant for power generation, which is so essential to growth. Given the importance of rural populations and the need to diversify exports, agriculture should also be taken into account in the priorities of the growth strategy incorporated into the program. 


\section{INTERNATIONAL MONETARY FUND}

EXTERNAL

Public Information Notice

Public Information Notice (PIN) No. 11/92

International Monetary Fund

$70019^{\text {th }}$ Street, NW

FOR IMMEDIATE RELEASE

Washington,

D. C. 20431 USA

July 19,2011

\section{IMF Executive Board Discusses the Ex Post Assessment of Longer-Term Program Engagement with Burundi}

On July 13, 2011, the Executive Board of the International Monetary Fund (IMF) discussed the Ex Post Assessment (EPA) of Longer-Term Program Engagement with Burundi. $^{1}$

\section{Background}

Burundi has been engaged with the Fund since 2002, through a Post-Conflict Emergency Assistance (2002-03) and two successive Poverty Reduction and Growth Facility (now Extended Credit Facility) arrangements. The EPA focuses on the latter two, covering the period since January 2004.

Despite steady improvements in civil peace and macroeconomic stability, economic development has remained constrained by weak institutions and governance, small and inefficient markets, poor infrastructure, and scarce capital, skills and technology. Growth has rebounded to pre-conflict levels, but remains volatile. Satisfactory performance under the programs secured considerable debt relief under the Heavily Indebted Poor Country (HIPC) and Multilateral Debt Relief Initiatives (MDRI), and encouraged a surge in external aid that boosted government outlays in priority sectors, but left the public sector highly dependent on foreign assistance. Notable progress was made on structural reforms aimed at improving the conduct of monetary and fiscal policies, but was much slower in other areas, especially the coffee sector (the main source of income

\footnotetext{
${ }^{1}$ An EPA is required for all members having longer-term program engagement with the Fund. It is intended to provide an opportunity for the Fund to step back from continuing program relations with a member country to consider an analysis of the economic problems facing the country, a review of progress under Fund-supported programs and forward-looking assessment that takes into account the lessons learned, and presents a strategy for future Fund engagement.
} 
for half of the population). Technical assistance has played an important role in enhancing the macroeconomic policy framework.

Looking forward, Burundi needs a growth strategy based on further reforms that alleviate key bottlenecks and guarantee stability-oriented macroeconomic policies. Priorities for macroeconomic policies include greater exchange rate flexibility to better absorb external shocks, and the need to save part of the growth dividends to build fiscal buffers and restore debt sustainability. Further technical assistance aimed at implementing recent institutional reforms and building up capacities will be essential.

\section{Executive Board Assessment}

Directors broadly agreed with the findings of the Ex-Post Assessment that Fund involvement in Burundi has supported sound macroeconomic policies, catalyzed external assistance, and spurred reforms on a broad front. More broadly, Burundi's experience highlights the importance of strong program ownership and wellcoordinated technical assistance and donor support. Directors noted that continued technical assistance and a successor program could cement macroeconomic stability and boost growth prospects.

Public Information Notices (PINs) form part of the IMF's efforts to promote transparency of the IMF's views and analysis of economic developments and policies. With the consent of the country (or countries) concerned, PINs are issued after Executive Board discussions of Article IV consultations with member countries, of its surveillance of developments at the regional level, of post-program monitoring, and of ex post assessments of member countries with longer-term program engagements. PINs are also issued after Executive Board discussions of general policy matters, unless otherwise decided by the Executive Board in a particular case. 
Burundi: Selected Economic and Financial Indicators, 2008-10 $20082009 \quad 2010$

(Annual percentage change)

\begin{tabular}{|c|c|c|c|}
\hline \multicolumn{4}{|l|}{ Real Economy } \\
\hline Real GDP growth & 4.5 & 3.5 & 3.9 \\
\hline Consumer prices (period average) & 24.4 & 10.7 & 6.4 \\
\hline \multirow[t]{2}{*}{ Consumer prices (end of period) } & 25.7 & 4.6 & 4.1 \\
\hline & \multicolumn{3}{|c|}{$\begin{array}{c}\text { (Change in percent of } \\
\text { beginning of period M2, } \\
\text { unless otherwise indicated) }\end{array}$} \\
\hline \multicolumn{4}{|l|}{ Money and credit } \\
\hline Net foreign assets & 21.9 & -2.9 & -5.4 \\
\hline Domestic credit & 18.8 & 27.8 & 24.2 \\
\hline \multirow[t]{2}{*}{ Money and quasi-money (M2) } & 34.2 & 19.8 & 19.4 \\
\hline & \multicolumn{3}{|c|}{ (Percent of GDP) } \\
\hline \multicolumn{4}{|l|}{ General government } \\
\hline Revenue (excluding grants) & 18.5 & 18.6 & 19.8 \\
\hline \multicolumn{4}{|l|}{ Overall balance (commitment basis) } \\
\hline Excluding grants & -38.2 & -32.1 & -34.9 \\
\hline Including grants (excl. HIPC) & -2.4 & -5.2 & -3.2 \\
\hline \multicolumn{4}{|l|}{ External sector } \\
\hline Current account balance & -15.0 & -16.1 & -13.4 \\
\hline \multicolumn{4}{|l|}{ Gross official reserves } \\
\hline US\$ million & 267 & 323 & 332 \\
\hline Months of imports & 5.0 & 5.0 & 4.8 \\
\hline
\end{tabular}

Sources: Burundi authorities and IMF staff estimates and projections. 